\title{
High resilience of carbon transport in long-term drought-stressed mature Norway spruce trees within 2 weeks after drought release
}

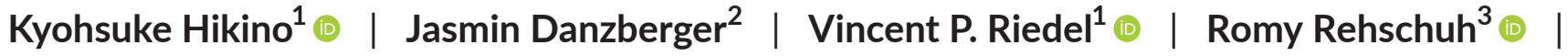

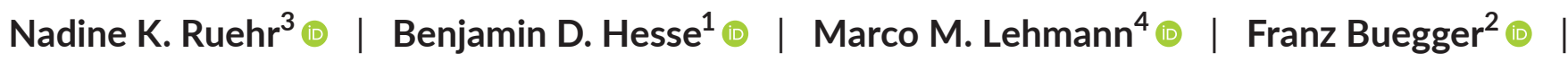

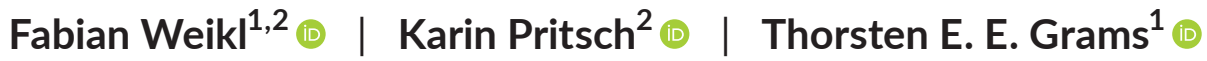 \\ ${ }^{1}$ Technical University of Munich (TUM), TUM School of Life Sciences, Land Surface-Atmosphere Interactions, Ecophysiology of Plants, Freising, Germany \\ ${ }^{2}$ Helmholtz Zentrum München - German Research Center for Environmental Health (GmbH), Institute of Biochemical Plant Pathology, Neuherberg, Germany \\ ${ }^{3}$ Karlsruhe Institute of Technology, Institute of Meteorology and Climate Research-Atmospheric Environmental Research (KIT/IMK-IFU), \\ Garmisch-Partenkirchen, Germany \\ ${ }^{4}$ Swiss Federal Institute for Forest, Snow and Landscape Research (WSL), Forest Dynamics, Birmensdorf, Switzerland
}

\author{
Correspondence \\ Kyohsuke Hikino, Technical University \\ of Munich (TUM), TUM School of Life \\ Sciences, Professorship for Land Surface- \\ Atmosphere Interactions, Ecophysiology \\ of Plants, Hans-Carl-von-Carlowitz Platz \\ 2, 85354 Freising, Germany. \\ Email: kyohsuke.hikino@tum.de \\ Present address \\ Vincent P. Riedel, University of Würzburg, \\ Julius-von-Sachs-Institute of Biological \\ Sciences, Ecophysiology and Vegetation \\ Ecology, Würzburg, Germany \\ Funding information \\ Deutsche Forschungsgemeinschaft, \\ Grant/Award Number: GR 1881/5-1, \\ MA1763/10-1, PR292/22-1, \\ PR555/2-1 and RU 1657/2-1; Deutsche \\ Bundesstiftung Umwelt, Grant/Award \\ Number: AZ 20018/535; Schweizerischer \\ Nationalfonds zur Förderung der \\ Wissenschaftlichen Forschung, Grant/ \\ Award Number: 179978; Bavarian State \\ Ministries of the Environment and \\ Consumer Protection as well as Food, \\ Agriculture and Forestry, Grant/Award \\ Number: W047/Kroof II
}

\begin{abstract}
Under ongoing global climate change, drought periods are predicted to increase in frequency and intensity in the future. Under these circumstances, it is crucial for tree's survival to recover their restricted functionalities quickly after drought release. To elucidate the recovery of carbon (C) transport rates in c. 70-year-old Norway spruce (Picea abies [L.] KARST.) after 5 years of recurrent summer droughts, we conducted a continuous whole-tree ${ }^{13} \mathrm{C}$ labeling experiment in parallel with watering. We determined the arrival time of current photoassimilates in major $\mathrm{C}$ sinks by tracing the ${ }^{13} \mathrm{C}$ label in stem and soil $\mathrm{CO}_{2}$ efflux, and tips of living fine roots. In the first week after watering, aboveground $\mathrm{C}$ transport rates (CTR) from crown to trunk base were still $50 \%$ lower in previously drought-stressed trees $\left(0.16 \pm 0.01 \mathrm{~m} \mathrm{~h}^{-1}\right)$ compared to controls $\left(0.30 \pm 0.06 \mathrm{~m} \mathrm{~h}^{-1}\right)$. Conversely, CTR below ground, that is, from the trunk base to soil $\mathrm{CO}_{2}$ efflux were already similar between treatments (c. $0.03 \mathrm{~m} \mathrm{~h}^{-1}$ ). Two weeks after watering, aboveground $\mathrm{C}$ transport of previously drought-stressed trees recovered to the level of the controls. Furthermore, regrowth of water-absorbing fine roots upon watering was supported by faster incorporation of ${ }^{13} \mathrm{C}$ label in previously drought-stressed (within $12 \pm 10 \mathrm{~h}$ upon arrival at trunk base) compared to control trees $\left(73 \pm 10 \mathrm{~h}\right.$ ). Thus, the whole-tree $\mathrm{C}$ transport system from the crown to soil $\mathrm{CO}_{2}$ efflux fully recovered within 2 weeks after drought release, and hence showed high resilience to recurrent summer droughts in mature Norway spruce forests. This high resilience of the $\mathrm{C}$ transport system is an important prerequisite for the recovery of other tree functionalities and productivity.
\end{abstract}


${ }^{13} \mathrm{C}$ labeling, climate change, forest ecosystem, phloem, photosynthesis, Picea abies, recovery, soil $\mathrm{CO}_{2}$ efflux, stem $\mathrm{CO}_{2}$ efflux, watering

\section{1 | INTRODUCTION}

Global climate change has been causing significant and mostly negative impacts on forest ecosystem carbon (C) cycling such as reduced productivity (Ciais et al., 2005; Collins et al., 2013). Drought is one of the most influential drivers of tree mortality (Allen et al., 2010; 2015; McDowell et al., 2008; van Mantgem et al., 2009) and it is predicted to occur more frequently and for longer durations in the future (IPCC, 2007, 2014). Under these circumstances, tree survival primarily depends on the extent to which tree functionality is impaired by drought (i.e., resistance, Lloret et al., 2011). After drought release, it is then crucial that surviving trees recover their limited functionality back to pre-drought levels (i.e., resilience, Lloret et al., 2011). Since drought release typically causes a high $C$ demand for repair and growth particularly in belowground sinks (Gao et al., 2021; Hagedorn et al., 2016; Joseph et al., 2020), C transport from leaves to sink organs is an important process for tree recovery (Ruehr et al., 2019). C assimilates are transported from the crown via the phloem to various above- and belowground C sinks (Lemoine et al., 2013; Salmon et al., 2019). Recent studies revealed that saplings (Barthel et al., 2011; Ruehr et al., 2009; Zang et al., 2014), young trees (Dannoura et al., 2019; Epron et al., 2016), and mature trees (Gao et al., 2021; Hesse et al., 2019; Wang et al., 2021) restricted transport of current photoassimilates under drought, thereby reducing the $C$ supply to sinks. Upon drought release, $C$ limitation in sink tissues can occur if the $C$ transport would not recover fast enough to meet the sink demands (Hartmann et al., 2013; Hartmann et al., 2013; Sevanto, 2014; Winkler \& Oberhuber, 2017), but knowledge on mature trees is scarce (Gao et al., 2021).

There are two main causes restricting transport of current photoassimilates from the crown along the stem to belowground $C$ sinks under drought (Salmon et al., 2019). First, water limitation delays the export of sugars from leaves, increasing the mean residence time (MRT) of photoassimilates in leaves (Dannoura et al., 2019; Epron et al., 2012; Hesse et al., 2019; Ruehr et al., 2009). This is caused by accumulation of osmolytes, and/or production of secondary metabolites and volatile compounds (Epron \& Dreyer, 1996; Ruehr et al., 2009; Salmon et al., 2019). Second, the phloem transport velocity can be reduced through increased phloem viscosity (Epron et al., 2016; Hesse et al., 2019; Sevanto, 2014, 2018; Woodruff, 2014), lower C source/sink strength (Lemoine et al., 2013; Ryan \& Asao, 2014; Sevanto, 2014), and smaller phloem conduit diameter (Dannoura et al., 2019; Woodruff, 2014). Increased phloem viscosity is a result of water limitation in the xylem, as the xylem supplies the nearby phloem with water (Hölttä et al., 2006, 2009). Lower C source/sink strength (e.g., photosynthesis rates and stem/soil $\mathrm{CO}_{2}$ efflux rates) limits sugar loading/unloading processes between $\mathrm{C}$ source/sink and phloem. This hinders the osmotic regulation in phloem and thus limits water exchange between phloem and xylem. Smaller phloem conduit diameter is caused by restricted cell expansion due to turgor reduction usually under severe drought (Hsiao, 1973), thereby reducing phloem conductivity.

Recovery of $\mathrm{C}$ transport depends on the restricting mechanisms. MRT of leaf sugars decreases after drought release within days (Zang et al., 2014). Drought release increases plant water potential and water availability in the xylem, typically followed by increased C source and sink strength (Gao et al., 2021; Hagedorn et al., 2016). Previous studies using young eucalypt trees (Epron et al., 2016) and a rainfall event in a naturally dry pine forest (Gao et al., 2021) reported that $\mathrm{C}$ transport velocity from crown to trunk base or soil was related to $C$ source or sink strength, which typically decreases under drought and increases after drought release (Hagedorn et al., 2016; Joseph et al., 2020; Nikolova et al., 2009; Zang et al., 2014). Furthermore, there is increasing evidence that $\mathrm{C}$ source strength and C supply may be "sink controlled" (Fatichi et al., 2014; Gavito et al., 2019; Hagedorn et al., 2016; Körner, 2015). Conversely, droughtrelated reductions of phloem conduit diameter are expected to further restrict the phloem transport during the first weeks after stress release even if the phloem sap viscosity and $C$ source/sink strength recover.

This present study was performed in the framework of the Kranzberg roof (KROOF) project, which was initiated to elucidate the drought responses of mature European beech (Fagus sylvatica L.) and Norway spruce (Picea abies [L.] KARST.; see details in Grams et al., 2021). Both tree species were exposed to recurrent summer droughts from 2014 to 2018 and leaf water potential reached values as low as -1.8 MPa, causing distinct drought effects such as reduced stem and fine root growth (Grams et al., 2021; Pretzsch et al., 2020; Zwetsloot \& Bauerle, 2021) and acclimation in tree hydraulics (Tomasella et al., 2018). To predict the trajectories of forests under future climates, it is important to understand, to what extent tree functionality recovers after drought release and how fast. To answer this question, former drought plots were watered in early summer 2019 (Grams et al., 2021). In parallel with watering, we performed a whole-tree ${ }^{13} \mathrm{C}$ labeling experiment on mature spruce trees to assess the resilience of their $C$ transport processes, that is, the ability to recover to the level of control trees (Lloret et al., 2011).

We divided the $\mathrm{C}$ transport path from the crown to the soil $\mathrm{CO}_{2}$ efflux into two parts (Figure 1), as drought release may affect them differently. (1) Aboveground transport from the crown (leaves) to the trunk base (aboveground transport hereafter), and (2) belowground transport from the trunk base to the soil $\mathrm{CO}_{2}$ efflux (belowground transport hereafter). In addition, we also investigated a third process, (3) incorporation of current photoassimilates in living fine roots (Figure 1). The aboveground transport comprises sugar export from leaves and transport along the woody structures in the 
FIGURE 1 Overview of the carbon transport paths assessed in this study. (1) Aboveground carbon transport rates $\left(C_{\text {above }}\right.$, in $\mathrm{m} \mathrm{h}^{-1}$ ) from crown to trunk base (assessed as stem $\mathrm{CO}_{2}$ efflux), (2) Belowground carbon transport rates $\left(\mathrm{CTR}_{\text {below, }}\right.$ in $\left.\mathrm{m} \mathrm{h}^{-1}\right)$ from trunk base to soil $\mathrm{CO}_{2}$ efflux, and (3) Incorporation time (in h) of current photoassimilates from trunk base to fine root tips

\section{${ }^{13} \mathrm{C}$-depleted} $\mathrm{CO}_{2}$

\section{(2) From trunk base to soil $\mathrm{CO}_{2}$ efflux ( $\mathrm{CTR}_{\text {below }}$ )}

\section{(1) From crown to trunk base (CTR above $)$}

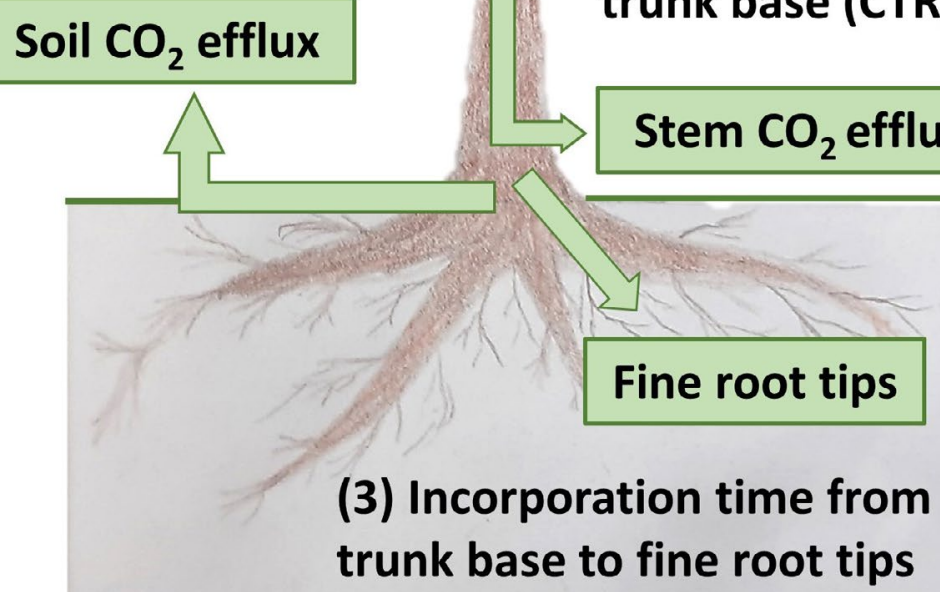

phloem. The aboveground $C$ transport rates $\left(\mathrm{CTR}_{\text {above }}\right.$ in $\left.\mathrm{m} \mathrm{h}^{-1}\right)$ indicate how fast newly assimilated $\mathrm{C}$ can be supplied to belowground sinks. The belowground transport includes the phloem transport along roots and the $\mathrm{CO}_{2}$ diffusion in the soil. The belowground $\mathrm{C}$ transport rates $\left(\mathrm{CTR}_{\text {below }}\right)$ indicate the rates of $\mathrm{C}$ flux from belowground plant tissues to the atmosphere, which is an important flux in analyzing forest $\mathrm{C}$ cycling. Based on the "sink-control" mechanism, we hypothesize that both $\mathrm{CTR}_{\text {above }}[\mathrm{H} 1]$ and $\mathrm{CTR}_{\text {below }}[\mathrm{H} 2]$ recover within 2 weeks in parallel to $C$ sink and/or $C$ source strength. The timing of the incorporation of current photoassimilates in fine roots indicates how fast trees use the available $C$ to grow and restore the belowground tissues. Since a high $\mathrm{C}$ demand is expected in fine root growth of recovering trees upon drought release, the incorporation time can be even shorter in recovering trees compared to control trees. Therefore, our third hypothesis is that upon drought release, incorporation of current photoassimilates is faster in fine roots of trees recovering from drought than in control trees [H3].

In a similar experiment by Gao et al. (2021) conducted in a naturally dry pine forest after a rainfall event is the only study to date investigating CTR of mature trees after drought release. We still lack knowledge on the recovery of highly productive forests under ongoing climate change. Furthermore, there is no study considering the effect of water availability on the above- and belowground transport individually. We show for the first time the resilience of the wholetree $\mathrm{C}$ transport after repeated summer droughts in a highly productive Norway spruce forest stand of great ecological and economic relevance in central Europe (Caudullo et al., 2016).

\section{2 | MATERIALS AND METHODS}

\subsection{Experimental site}

This study was conducted in a mixed forest with c. 90-year-old European beech and c. 70-year-old Norway spruce trees in Kranzberg Forest, located in southern Germany/Bavaria $\left(11^{\circ} 39^{\prime} 42^{\prime \prime} \mathrm{E}, 48^{\circ} 25^{\prime} 12^{\prime \prime} \mathrm{N} ; 490 \mathrm{~m}\right.$ a.s.l.). The experimental site consists of 12 plots with three to seven beech and spruce trees each. At this site, a long-term throughfall exclusion (TE) and subsequent watering experiment was conducted as described in detail 
in Grams et al. (2021). Briefly, six plots were assigned to TE plots equipped with roofs and the other six plots without roofs to control plots (CO). All plots were trenched to $1 \mathrm{~m}$ of soil depth 4 years before the experiments started (Pretzsch et al., 2014). The mature beech and spruce trees in TE plots were then exposed to summer drought for five consecutive growing seasons (2014-2018). To investigate trees' recovery processes, in early summer 2019, all TE plots were watered with c. $90 \mathrm{~mm}$ over $36 \mathrm{~h}$ and the soil water content increased to the level of the CO plots within 1 week (for further details see Grams et al., 2021). In parallel with the watering, we conducted $a^{13} \mathrm{C}$ labeling experiment on four $\mathrm{CO}$ and three TE spruce trees on neighboring plots (Figure 2a, for details see Table S1). In addition to the two labeled plots, we assessed three spruce trees each on additional $\mathrm{CO}$ and TE plots as non-labeled controls (Table S2). A canopy crane located next to these plots enabled the measurements of leaf photosynthesis, leaf water potential, and leaf osmotic potential in sun-lit canopy.

\subsection{Weather data}

The mean photosynthetic photon flux density during the labeling period accounted to $788 \pm 534$ (SD) $\mu \mathrm{mol} \mathrm{m}^{-2} \mathrm{~s}^{-1}$ (Figure 3a). During the daytime (from 5 am to $7 \mathrm{pm}, \mathrm{CET}$ ) on the labeling days, mean temperature was $18.8 \pm 4.3(\mathrm{SD}){ }^{\circ} \mathrm{C}$ (Figure $3 \mathrm{~b}$ ) and mean vapor pressure deficit was $0.6 \pm 0.4$ (SD) $\mathrm{kPa}$. There were several rain periods during labeling on day 3, 7, and 9. Only on day 9, however, weak but continuous rainfall event with a high wind speed occurred throughout the daytime, accumulating to $7.8 \mathrm{~mm}$ (Figure $3 \mathrm{~b}$ ). Due to this weather conditions, a smaller $\delta^{13} \mathrm{C}$ shift in canopy air was achieved on day 9 (see below).

\section{3 $\mathrm{CO}_{2}$ exposure and assessment of canopy air}

The whole crowns of all spruce trees on the CO and TE plot, that is, four and three trees, respectively, were fumigated with ${ }^{13} \mathrm{C}$-depleted tank $\mathrm{CO}_{2}\left(\delta^{13} \mathrm{C}\right.$ of $-44.3 \pm 0.2 \%$ ) using the isoFACE system described earlier (Grams et al., 2011; Kuptz et al., 2011). Depending on its crown size, each tree crown was equipped with 9-17 microperforated PVC tubes hanging vertically from a carrier structure (Figure 2b). These fumigation tubes were then connected to the $\mathrm{CO}_{2}$ tank and the ${ }^{13} \mathrm{C}$-depleted $\mathrm{CO}_{2}$ was released directly within the seven tree crowns.

The atmospheric $\mathrm{CO}_{2}$ concentration and $\delta^{13} \mathrm{C}$ in tree canopy $\left(\delta^{13} C_{a}\right)$ were continuously monitored during the labeling using a cavity ring-down spectroscopy (CRDS, ESP-1000; PICARRO). Two air measurement points were installed per tree c. $2 \mathrm{~m}$ inside the sun-lite crowns at $1 \mathrm{~m}$ distance from the stem (east and west orientation, one $\mathrm{CO}$ tree had only one measurement point, Figure 2a and Table S2). We took care that these sampling points had enough distances from the fumigation tubes (c. $1 \mathrm{~m}$ ). A sample point above the canopy was used as a reference. The sample air was continuously transported to the CRDS by membrane pumps via PVC tubes. A computerautomated multiplexer system switched every 5 min between measurement positions and averages of the last 3 min were recorded by the CRDS. According to the mean $\mathrm{CO}_{2}$ concentration of all 13 measurement points in canopy, which was measured continuously by an infra-red gas analyzer (BINOS 100 4P; Rosemount-Emerson Electric Co.), a mass flow controller regulated the amount of the $\mathrm{CO}_{2}$ exposure through fumigation tubes. To calibrate the CRDS, two commercially available calibration gases were used (Ref.1: $-9.7 \pm 0.3 \%$ and Ref.2: $-27.8 \pm 0.3 \%$; Thermo Fisher Scientific). All $\delta^{13} \mathrm{C}$ values in this study were referenced to international standards (Vienna Pee Dee Belemnite).

The ${ }^{13} \mathrm{C}$ labeling started in parallel with the watering and continued for 14 days, that is, from July 4, 2019 (day 0) to July 17, 2019 (day 13), from 5 am to 7 pm (CET). We targeted the mean $\mathrm{CO}_{2}$ concentration in canopy air at $+130 \mathrm{ppm}$ relative to the ambient air above the canopy to create a shift of $-8.3 \%$. Due to variable wind exposition, however, each tree received different amounts of added $\mathrm{CO}_{2}$. In $\mathrm{CO}$ trees, the mean canopy $\mathrm{CO}_{2}$ concentration increased to $541 \pm 16 \mathrm{ppm}$ during labeling (Figure 3c, see values for individual trees in Table S1), shifting the $\delta^{13} C_{a}$ by (a)

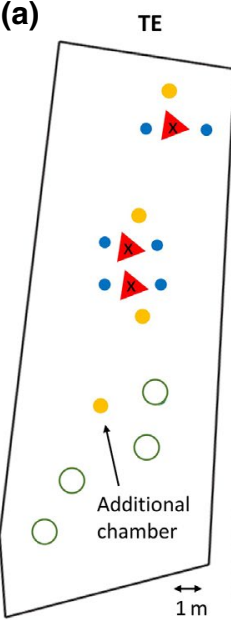

(b)

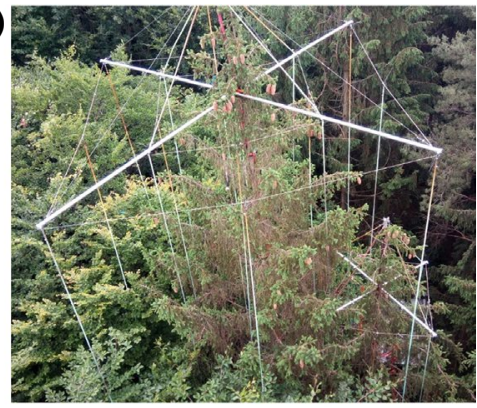

FIGURE 2 (a) Overview of the two ${ }^{13} \mathrm{C}$-labeled plots $(\mathrm{CO}=$ control, $\mathrm{TE}=$ throughfall exclusion), giving positions of trees (red triangles = labeled spruce trees, green open circles $=$ beech), sampling positions of canopy air (blue circles), stem $\mathrm{CO}_{2}$ efflux (x), and soil $\mathrm{CO}_{2}$ efflux (yellow circles). (b) Picture of the structure for the ${ }^{13} \mathrm{C}$ labeling with PVC tubes hanging vertically through the spruce crowns 

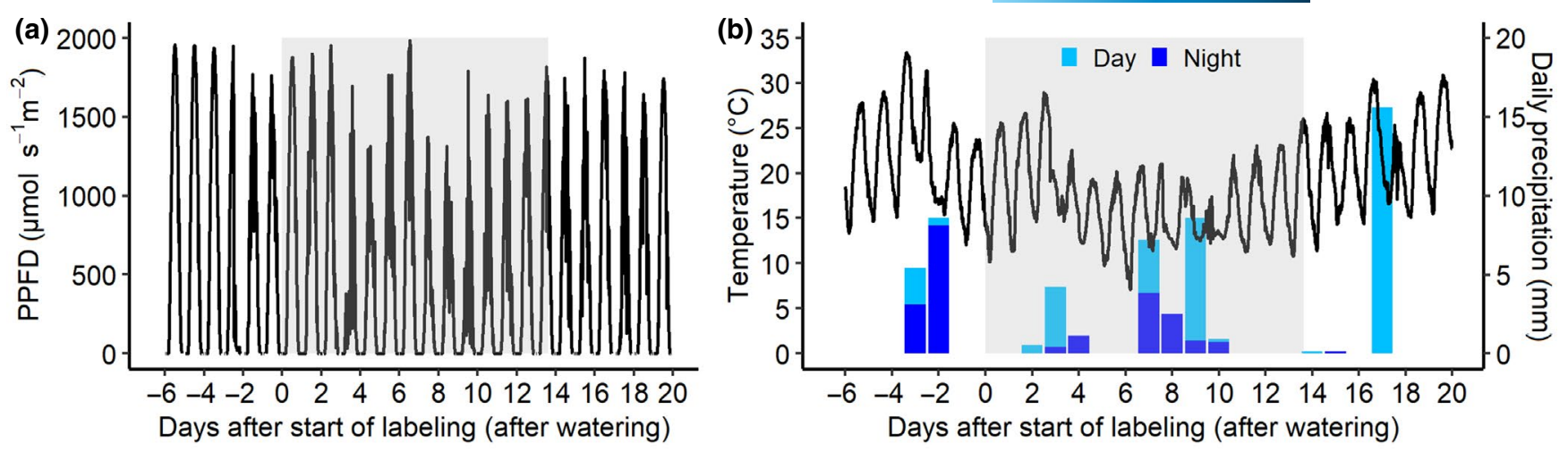

(c) CO canopy

(d)
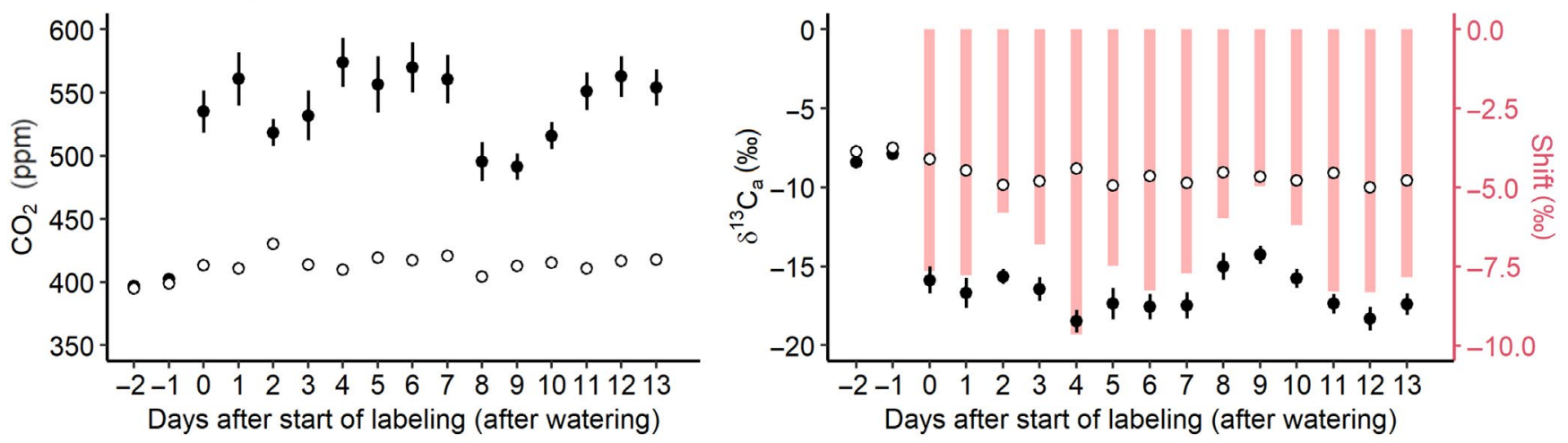

(e) TE canopy

(f)
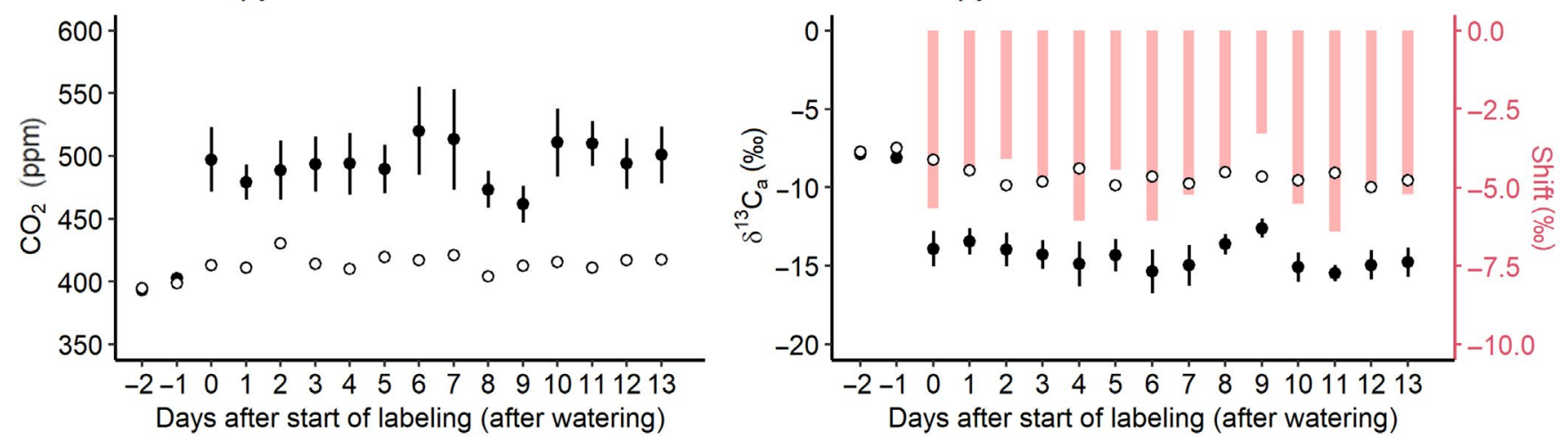

FIGURE 3 (a) Photosynthetic photon flux density (PPFD) before, during, and after labeling. (b) Temperature (lines) and precipitation (bars) before, during, and after labeling. Precipitation is given as daytime ( $5 \mathrm{am}-7 \mathrm{pm}$ CET, fumigation hours, light blue), and nighttime (7 pm$5 \mathrm{am}$, dark blue). The ticks on the $x$-axis indicate 0 am of each day. The labeling started in parallel with the watering on day 0 and continued during daytime until day 13 (marked with gray areas). (c, e) Daily mean $\mathrm{CO}_{2}$ concentration and $(\mathrm{d}, \mathrm{f}) \delta^{13} \mathrm{C}$ of canopy air ( $\delta^{13} \mathrm{C}$ ) of control (CO) and previously drought-stressed (throughfall exclusion, TE) trees during labeling hours ( $5 \mathrm{am}-7 \mathrm{pm}$ ), respectively. The closed circles are the averages of the canopy air and the open circles are the non-labeled reference air measured above the canopy. The mean daily shift in $\delta^{13} C_{a}$ was expressed with red bars. Error bars give SE. Error bars of the reference air (open circles) are removed, as they are much shorter than the size of the circles due to the large amount of measurement points

$-7.3 \pm 0.5 \%$ o on average (Figure $3 \mathrm{~d}$ ). In contrast, TE trees received less ${ }^{13} \mathrm{C}$-depleted $\mathrm{CO}_{2}$ with an increase in the mean canopy $\mathrm{CO}_{2}$ concentration to $495 \pm 23 \mathrm{ppm}$ (Figure 3e), causing smaller mean shift of $\delta^{13} C_{a}$ by $-5.1 \pm 1.3 \%$ (Figure 3f) compared to $\mathrm{CO}$ trees. Furthermore, during the weak but longer rainfall event associated with a high wind speed on day 9 , a smaller mean shift in $\delta^{13} \mathrm{C}_{\mathrm{a}}$ was achieved in both $\mathrm{CO}$ and TE trees. Mean $\mathrm{CO}_{2}$ concentration and $\delta^{13} \mathrm{C}$ of the ambient air above the canopy were $413 \mathrm{ppm}$ and $-9.2 \%$ o during labeling hours.
To track the current photoassimilates through the tree/soil system, we used the two experimentally induced changes in $\delta^{13} \mathrm{C}_{\mathrm{a}}$ : (1) Turn-on of $\mathrm{CO}_{2}$ exposure with ${ }^{13} \mathrm{C}$-depleted tank $\mathrm{CO}_{2}$ on day 0 of watering. This part of the experiment was used to calculate the arrival time of the ${ }^{13} \mathrm{C}$-depleted tracer in the observed $\mathrm{C}$ sinks in the first week after watering. (2) Turn-off of the $\mathrm{CO}_{2}$ exposure system and subsequent increase in $\delta^{13} \mathrm{C}$ in the canopy air back to the initial, ambient level on day 13 of watering. In this part of the experiment, the arrival of unlabeled tracer ( $\mathrm{C}$ with ambient $\delta^{13} \mathrm{C}$ ) 
in the studied C sinks was used to calculate CTR 2 weeks after watering.

\section{4 | Measurement of phloem sugar}

On day $-1,7,13$, and 21 around midday, phloem tissue samples were collected at the breast height of four labeled $\mathrm{CO}$ and three labeled TE trees using a cork borer (two disks with diameter of $5 \mathrm{~mm}$ for each tree, Tables S2 and S3). The dead bark was removed and the remaining phloem samples were immediately frozen on dry ice and subsequently freeze-dried. The dried material was milled to fine powder using a steel ball-mill (Retsch) and about $70 \mathrm{mg}$ per sample were transferred into a $2 \mathrm{ml}$ reaction vial and mixed with $1.5 \mathrm{ml}$ deionized water. The fractions of water-soluble compounds were then extracted in a water bath at $85^{\circ} \mathrm{C}$ for $30 \mathrm{~min}$ and further purified to neutral sugars using commercial available ion-exchange cartridges (OnGuard II H, A, \& P; Dionex) as described in detail by Lehmann et al. (2020). An aliquot of $1 \mathrm{mg}$ of the neutral sugar fraction was then transferred to $5 \times 9 \mathrm{~mm}$ silver capsules (Saentis Analytical AG), frozen at $-20^{\circ} \mathrm{C}$, freeze-dried, and the capsules were closed before isotopic analysis. The $\mathrm{C}$ isotopic composition of phloem sugars $\left(\delta^{13} C_{\text {phloem }}\right)$ was analyzed with a thermal conversion elemental analyzer (PYRO cube; Elementar) that was coupled via a ConFlo III reference system to an isotope-ratio mass spectrometer (Finnigan Delta Plus XP, all supplied by Thermo Fisher Scientific). The typical measurement precision for in-house sugar standards was $0.3 \%$ (SD).

\section{5 | Measurement of stem $\mathrm{CO}_{2}$ efflux}

Rates of stem $\mathrm{CO}_{2}$ efflux and its stable $\mathrm{C}$ isotope composition $\left(\delta^{13} C_{\text {stem }}\right)$ before and after watering were recorded using an isotope ratio infrared spectrometer (IRIS, DeltaRay, Thermo Fisher Scientific; Braden-Behrens et al., 2017). A total of 12 spruce trees were measured, three ${ }^{13} \mathrm{C}$-labeled and three non-labeled trees in each treatment, that is, CO and TE ( $n=3$; Figure 2a; Tables S2 and S3). The non-labeled trees were used to correct for changes in ${ }^{13} \mathrm{C}$ discrimination caused by the watering and weather fluctuations. Plexiglas (Röhm GmbH) chambers $\left(61-204 \mathrm{~cm}^{2}\right.$ ) were attached at ca. $1 \mathrm{~m}$ height on each stem after removing mosses, lichens, and algae. After a leak test using a slight overpressure (c. $2000 \mathrm{~Pa}$ ), each chamber was supplied with reference air of a constant $\mathrm{CO}_{2}$ concentration of c. 413 ppm. Excess air was exhausted before entering the chamber to avoid an overpressure. The mixture of reference air plus stemderived $\mathrm{CO}_{2}$ of each chamber was continuously pumped through PVC tubes to a computer-automated manifold with 16 channels, which changed the channel flowing to IRIS every $5 \mathrm{~min}$. The $\mathrm{CO}_{2}$ concentration and the stable $\mathrm{C}$ isotope composition of the reference air were determined between measurement cycles (c. every $80 \mathrm{~min}$ ). The same reference gases as for the CRDS system were used for calibration of the IRIS system (see above).
The rate of stem-derived $\mathrm{CO}_{2}$ efflux was calculated according to mass balance equation as described by Gamnitzer et al. (2009), using the mean values of the closest two measurements of the reference air.

Stem $\mathrm{CO}_{2}$ efflux $\left(\mu \mathrm{mol} \mathrm{m}{ }^{-2} \mathrm{~s}^{-1}\right)=\frac{F_{\text {air }}}{V_{\text {mol }} A_{\text {chamber }}}\left(\left[\mathrm{CO}_{2}\right]_{\text {sample }}-\left[\mathrm{CO}_{2}\right]_{\text {reference }}\right)$,

where $F_{\text {air }}$ gives the air flow through the chamber $\left(\mathrm{L} \mathrm{s}^{-1}\right) ; \mathrm{V}_{\text {mol }}$, the molar volume of gases (22.4 $\left.\mathrm{L} \mathrm{mol}^{-1}\right)$; $A_{\text {chamber' }}$ the chamber base area $\left(\mathrm{m}^{2}\right)$; $\left[\mathrm{CO}_{2}\right]_{\text {sample }}$ and $\left[\mathrm{CO}_{2}\right]_{\text {reference }}$, the $\mathrm{CO}_{2}$ concentration (ppm) of sample air from stem chambers and reference air, respectively.

$\delta^{13} \mathrm{C}_{\text {stem }}$ was calculated by the following equation using a two end-member mixing model (Dawson et al., 2002),

$\delta^{13} \mathrm{C}_{\text {stem }}(\%, 0)=\frac{\left(\left[\mathrm{CO}_{2}\right]_{\text {sample }} \times \delta^{13} \mathrm{C}_{\text {sample }}\right)-\left(\left[\mathrm{CO}_{2}\right]_{\text {reference }} \times \delta^{13} \mathrm{C}_{\text {reference }}\right)}{\left[\mathrm{CO}_{2}\right]_{\text {sample }}-\left[\mathrm{CO}_{2}\right]_{\text {reference }}}$,

where $\delta^{13} \mathrm{C}_{\text {sample }}$ and $\delta^{13} \mathrm{C}_{\text {reference }}$ give the $\delta^{13} \mathrm{C}$ signature of sample air from stem chambers and that of reference air, respectively.

$\delta^{13} \mathrm{C}_{\text {stem }}$ can be affected by $\mathrm{CO}_{2}$ transported from belowground in xylem sap (Teskey et al., 2008). However, Kuptz et al. (2011) observed a positive correlation in $\delta^{13} \mathrm{C}$ between stem phloem and stem $\mathrm{CO}_{2}$ efflux in spruce trees at the same experimental site. In this study, we also found a positive linear correlation between $\delta^{13} \mathrm{C}_{\text {stem }}$ and $\delta^{13} C_{\text {phloem }}$ (slope $=0.94, R^{2}=.30, p<.01$; Figure S1). Likewise, $\delta^{13} C_{\text {stem }}$ showed no significant difference between daytime and nighttime (data not shown). Therefore, as reported in previous studies (Kodama et al., 2008; Kuptz et al., 2011; Ubierna et al., 2009), we concluded that $\mathrm{CO}_{2}$ in xylem sap had negligible effect on $\delta^{13} \mathrm{C}_{\text {stem }}$. Thus, we assessed the $\delta^{13} C_{\text {stem }}$ as a surrogate of $\delta^{13} C_{\text {phloem }}$.

\subsection{Measurement of soil $\mathrm{CO}_{2}$ efflux}

Soil $\mathrm{CO}_{2}$ efflux rates and its isotopic $\mathrm{C}$ composition $\left(\delta^{13} \mathrm{C}_{\text {soil }}\right)$ were measured using a $\mathrm{Li}-8100$ automated soil $\mathrm{CO}_{2}$ flux system with a Li-8150 multiplexer (Li-Cor Inc.), connected to an IRIS. The air stream leaving the Li-8100 was sampled by the IRIS at a flow rate of $80 \mathrm{ml} \mathrm{min}^{-1}$ and added back to the chamber air stream. Three automatically operating soil chambers (8100-104) per treatment, that is, $\mathrm{CO}$ and TE, were installed with $1 \mathrm{~m}$ distance from the spruce trees (Figure 2a; Table S2). Additionally, one chamber was installed close to the non-labeled beech trees in the TE plot (Figure 2a), which was used to correct for effects of physical $\mathrm{CO}_{2}$ diffusion due to watering (see the last paragraph of this section). Each chamber enclosed a permanently installed soil collar, which was inserted $2-3 \mathrm{~cm}$ into the soil 3 days before the measurements started. All chambers were measured at a frequency of c. $30 \mathrm{~min}$ (Table S3). Measurement time per chamber was adapted based on the $\mathrm{CO}_{2}$ efflux rate: 5 min in the TE plot and 2:30 min in the CO plot. $\delta^{13} \mathrm{C}_{\text {soil }}$ was calculated using the Keeling plot approach (Keeling, 1958, 1961). Each single measurement was quality controlled based on the fit of the linear regressions. For soil $\mathrm{CO}_{2}$ efflux values were kept if $R^{2} \geq .8$ and for 
$\delta^{13} C_{\text {soil }}$ based on the Keeling plot approach if $R^{2} \geq .9$. To calibrate the IRIS, two commercially available calibration gases were used (Ref.1: $-9.9 \pm 0.3 \%$ and Ref.2: $-27.8 \pm 0.3 \%$ o, Thermo Fisher Scientific).

During watering of the TE plots, the soil pores fill with water and the lighter ${ }^{13} \mathrm{C}$-depleted $\mathrm{CO}_{2}$ gets pushed-out (Andersen et al., 2010; Subke et al., 2009; Unger et al., 2010). This interfered with our labeling experiment. Hence, we corrected for the $\delta^{13} C_{\text {soil }}$ of the TE plot based on measurements of the additional chamber close to the non-labeled beech trees (see details in Figures S2 and S3). Due to a limitation in the number of soil chambers, a non-labeled chamber was not available for the $\mathrm{CO}$ plot. For purposes not related to this study, the CO plot was slightly watered (c. $12 \mathrm{~mm}$ over $12 \mathrm{~h}$ ) in parallel to the TE plots. As we did not observe any significant effect of the watering on the $\delta^{13} \mathrm{C}_{\text {soil }}$ of the wet CO plot (Figure $4 \mathrm{c}$ ), there was no need to apply this correction here.

\section{7 | Measurement of root tips}

Fine roots were collected on day -7 and repeatedly after the watering with an interval of 1-2 days until day 25 (Table S3), from random sampling positions (17-18 samples per treatment and day, Table S2). The collected samples were carefully washed in petri dishes, and representative living root tips were cut off under a stereomicroscope. Individual root tips were placed in pre-weighed tin capsules and dried at $60^{\circ} \mathrm{C}$. Their stable $\mathrm{C}$ isotope composition $\left(\delta^{13} \mathrm{C}_{\text {root }}\right)$ was determined with an isotope-ratio mass spectrometer (delta $\checkmark$ Advantage; Thermo Fisher Scientific) coupled to an Elemental Analyzer (Euro EA; Eurovector). Due to the very small sample quantities (the smallest samples with c. $3 \mu \mathrm{g} \mathrm{C)}$, the C-blank (c. $0.6 \mu \mathrm{g} \mathrm{C)} \mathrm{of}$ the tin capsules and their $\delta^{13} \mathrm{C}$ were taken into account in the evaluation. As with $\delta^{13} \mathrm{C}_{\text {stem }}, \delta^{13} \mathrm{C}_{\text {root }}$ of non-labeled plots was assessed to correct for the effect of watering and weather fluctuations.

\subsection{Calculation of arrival time and CTR}

To determine the arrival time of the two tracers $\left({ }^{13} \mathrm{C}\right.$-depleted tracer after the start of labeling, and unlabeled tracer after the end of labeling) in stem/soil $\mathrm{CO}_{2}$ efflux and living root tips, the courses of $\delta^{13} \mathrm{C}$ were fitted by piecewise function (Figure 4). Since ${ }^{13} \mathrm{C}$-depleted $\mathrm{CO}_{2}$ decreases $\delta^{13} \mathrm{C}$, the arrival time of the ${ }^{13} \mathrm{C}$-depleted tracer was defined as the point when $\delta^{13} \mathrm{C}$ started to decrease. First, $\delta^{13} \mathrm{C}$ data of each $\mathrm{C}$ sink were cut to contain only two linear segments before and after the arrival of the tracers. Then, we performed a linear regression for the $\delta^{13} \mathrm{C}$ data ("Im" function, R package "stats," version: 3.6.1). Finally, the intersection of two linear fits was determined using "segmented" function (R package "segmented," version: 1.3-0, red lines fitted to the $\delta^{13} \mathrm{C}$ data). This function calculated a new regression model and automatically estimated the break point (intersection) of two lines including standard errors, where the linear relationship changed. This intersection was then defined as the arrival time of the ${ }^{13} \mathrm{C}$-depleted tracer (red vertical lines in Figure $4 \mathrm{a}-\mathrm{f}$ ). In the case of soil $\mathrm{CO}_{2}$ efflux, the first line before arrival was fitted as a horizontal line (Figure 4c,d). After the end of labeling, $\delta^{13} \mathrm{C}$ of each $\mathrm{C}$ sink started to increase again, as the unlabeled tracer (with ambient $\delta^{13} \mathrm{C}$ values) arrived. This point of increasing $\delta^{13} \mathrm{C}$ was calculated with the same method described above (blue lines fitted to the $\delta^{13} \mathrm{C}$ data) and was then defined as the arrival time of unlabeled $C$ (blue vertical lines in Figure 4a-f). In the case of root tips, it was not possible to assign each root to the belonging tree. Therefore, all values were pooled for each treatment (Figure 4e,f), providing only one arrival time for each treatment.

Using the arrival time in stem and soil $\mathrm{CO}_{2}$ efflux, the $\mathrm{CTR}_{\text {above }}$ (aboveground $\mathrm{C}$ transport rates from crown to trunk base in $\mathrm{m} \mathrm{h}^{-1}$, Figure 1) and $\mathrm{CTR}_{\text {below }}$ (belowground $\mathrm{C}$ transport rates from trunk base to soil $\mathrm{CO}_{2}$ efflux in $\mathrm{m} \mathrm{h}^{-1}$, Figure 1 ) were calculated by:

$$
\operatorname{CTR}\left(\mathrm{mh}^{-1}\right)=\frac{d}{t l}
$$

For $\mathrm{CTR}_{\text {above, }}, \mathrm{tl}$ (in $\mathrm{h}$ ) gives the time lag between the start respectively end of labeling and the arrival time of the tracers at trunk base (stem $\mathrm{CO}_{2}$ efflux). $d$ (in $\mathrm{m}$ ) represents the distance between the mean crown height (the middle of the crown, Table S1) of the tree and the height of the stem chamber. For CTR below, $t$ ( in h) gives the time lag between the arrival time of the tracers at trunk base and the arrival time at soil $\mathrm{CO}_{2}$ efflux, with $d$ (in $\mathrm{m}$ ) representing the height of the stem chamber plus $1 \mathrm{~m}$, since each soil chamber was placed at $1 \mathrm{~m}$ distance from each trunk. The real transport distance from trunk base to soil chamber can vary depending on the structure of roots. We assumed that there is no time lag between arrival of current photoassimilates at trunk base/roots and the use of them in stem/root $\mathrm{CO}_{2}$ efflux. We did not calculate CTR to living root tips, since the transport distance was unknown due to random sampling positions. Therefore, for the incorporation time of current photoassimilates in fine roots, the time lags between the arrival time of the tracers at trunk base and the arrival time at root tips were compared between $\mathrm{CO}$ and TE trees instead (Figure 1).

The additional soil chamber in the TE plot enabled to correct for the effects of watering on $\delta^{13} \mathrm{C}_{\text {soil }}$ (see details in Figures S2 and S3). Due to stable weather conditions in the first week of the labeling with only few short and weak rain events, we were able to calculate the arrival time of ${ }^{13} \mathrm{C}$-depleted tracer in soil $\mathrm{CO}_{2}$ efflux. However, unstable weather conditions during the second part of the experiment (day 7-13) did not allow to calculate the arrival time of unlabeled tracer in soil $\mathrm{CO}_{2}$ efflux (they caused negative time lags). Reduced $\mathrm{C}$ gain on day 9 increased the $\delta^{13} C_{\text {soil }}$ already before the unlabeled tracer arrived in soil $\mathrm{CO}_{2}$ efflux, likely as more ${ }^{13} \mathrm{C}$-enriched old $\mathrm{C}$ was used (Steinmann et al., 2004; Wingate et al., 2010). Thus, we excluded the $\mathrm{CTR}_{\text {below}}$, calculated using unlabeled tracer 2 weeks after watering.

\subsection{Measurement of light-saturated $\mathrm{CO}_{2}$ assimilation rates $\left(A_{\text {sat }}\right)$, predawn leaf water potential $\left(\Psi_{\mathrm{PD}}\right)$, and leaf osmotic potential $\left(\pi_{\mathrm{O}}\right)$}

The light-saturated $\mathrm{CO}_{2}$ assimilation rates at $\mathrm{CO}_{2}$ concentration of $400 \mathrm{ppm}\left(\mathrm{A}_{\mathrm{sat}}\right.$, expressed on the basis of total needle surface area) 
CO
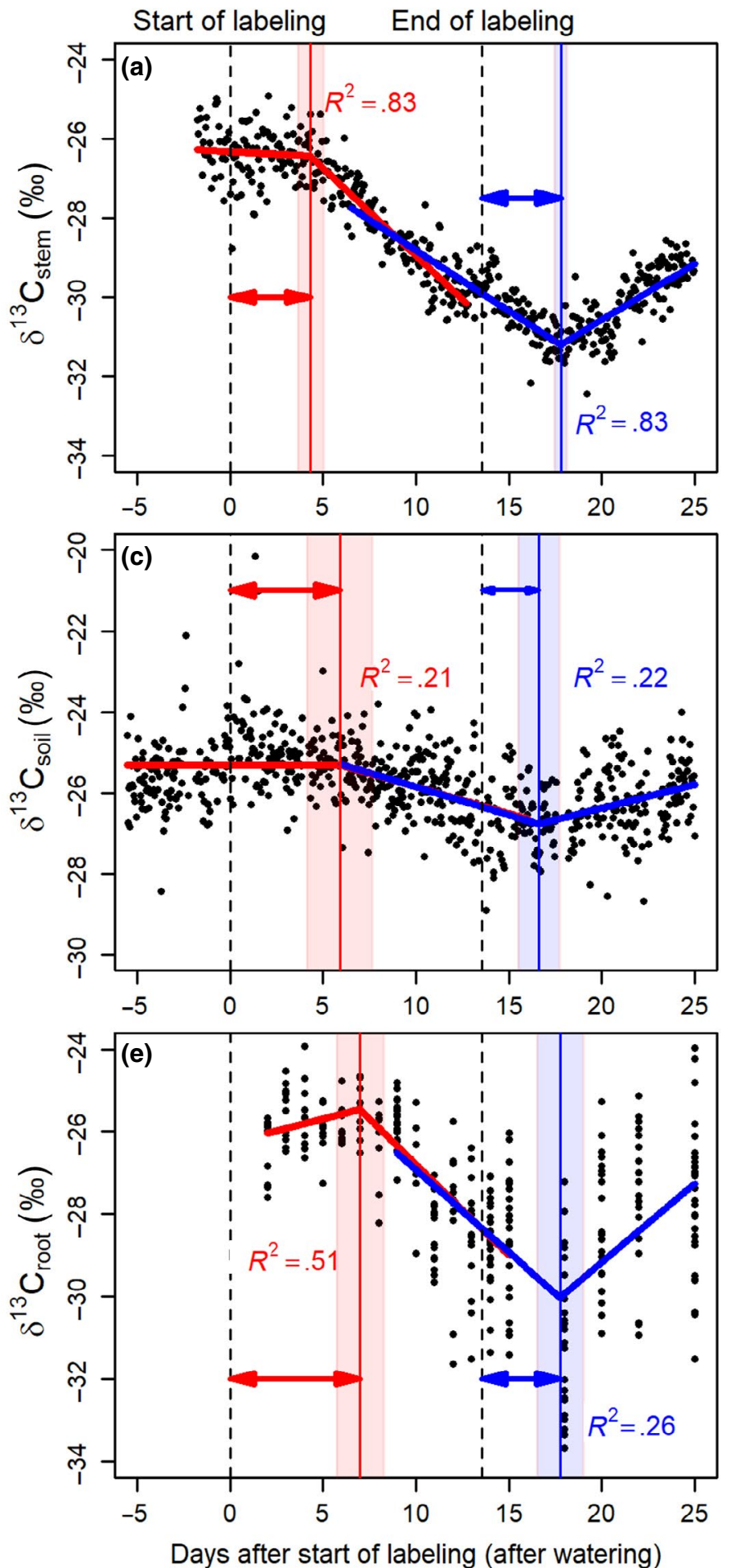

TE
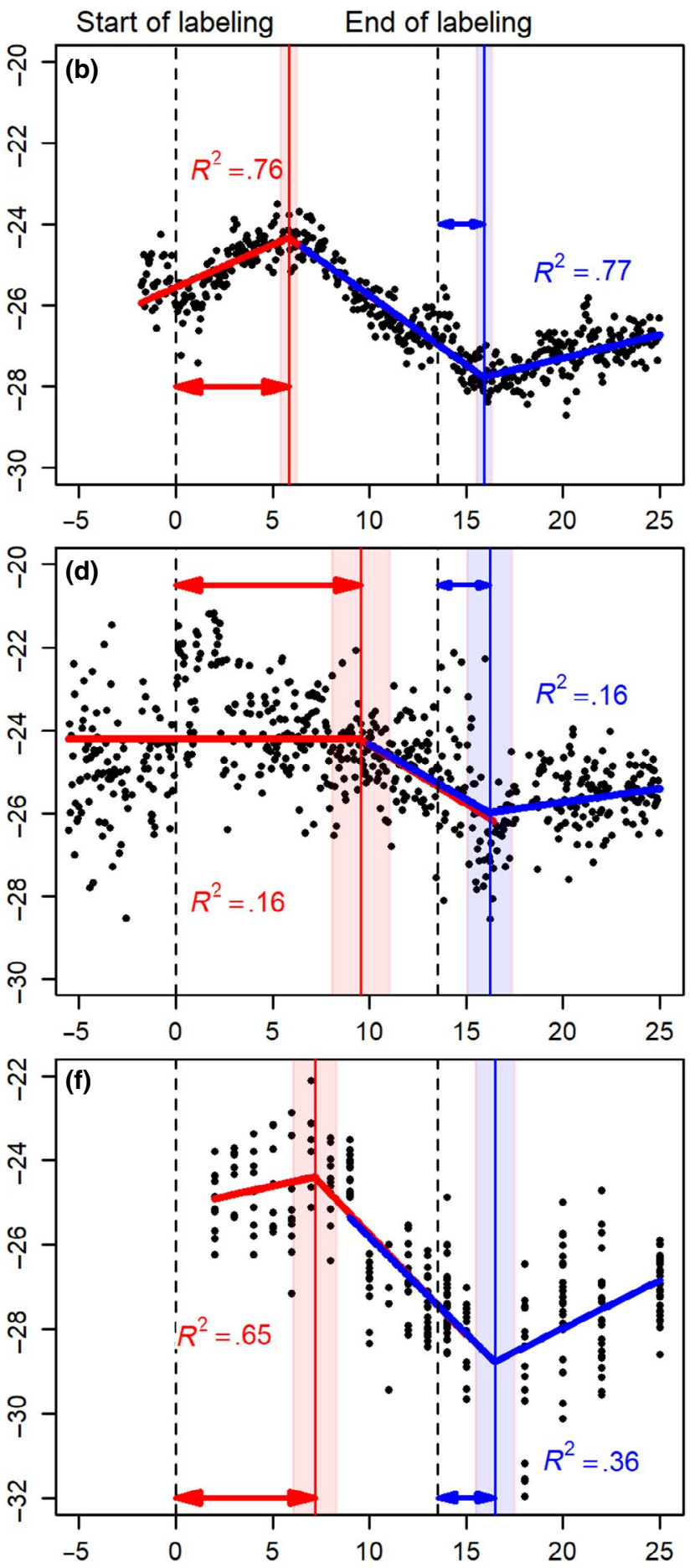

Days after start of labeling (after watering)

FIGURE 4 Examples for the calculation of the arrival time of the ${ }^{13} \mathrm{C}$-tracers, using: $(\mathrm{a}, \mathrm{b}) \delta^{13} \mathrm{C}$ of stem $\mathrm{CO}_{2}$ efflux $\left(\delta^{13} \mathrm{C}_{\text {stem }}\right.$ ) of one control (CO) and one previously drought-stressed (throughfall exclusion, TE) tree, (c, d) $\delta^{13} \mathrm{C}$ of soil $\mathrm{CO}_{2}$ efflux $\left(\delta^{13} \mathrm{C}_{\text {soil }}\right.$ ) of one CO and one TE soil chamber, and $(e, f) \delta^{13} \mathrm{C}$ of living root tips $\left(\delta^{13} \mathrm{C}_{\text {root }}\right)$ of $\mathrm{CO}$ and TE trees. Dashed vertical lines are the start and the end of labeling. The red and blue lines fitted to the data show the results of the piecewise functions to estimate the arrival time of ${ }^{13} \mathrm{C}$-depleted and unlabeled tracer, respectively (see Section 2). The intersections of two lines, marked with solid red and blue vertical lines are the calculated arrival times in the first week and 2 weeks after the watering, respectively. These arrival times (displayed here with arrows) were then used to calculate the above- and belowground carbon transport rates $\left(\mathrm{CTR}_{\text {above }}, \mathrm{CTR}_{\text {below }}\right)$ and the incorporation time in fine roots (see Section 2). The red and blue shaded area give the $95 \%$ confidence interval of the intersections. The data of the other trees are displayed in $\mathrm{Figure} \mathrm{S}_{4}$ (stem $\mathrm{CO}_{2}$ efflux) and in Figures S3 and S5 (soil $\mathrm{CO}_{2}$ efflux). All the root samples were pooled for each plot (CO and TE) 
were measured on fully sun-exposed 1-year-old needles using a LI6800 gas exchange system (Li-Cor Inc.) between 8 am and 3 pm (CET), before (around day -14) and after watering on days 4 and 14 (Table S3). In TE trees, when annual branch growth was not sufficiently long to cover the measurement chamber, needles from the previous year(s) were also included. Because of the small number of replicates in the present labeling plots (access by the canopy crane was limited by the labeling infrastructure), we additionally measured four spruce trees of each treatment in other plots (in total $n=6$; Table S2). During the measurements, we set the light intensity to $1500 \mu \mathrm{mol} \mathrm{m} \mathrm{s}^{-2}$ and kept the leaf temperature at $25^{\circ} \mathrm{C}$. The relative humidity was set to $60-65 \%$. After the measurements, the needles were harvested and scanned (Epson Perfection 4990 Photo; Epson Deutschland $\mathrm{GmbH}$ ). The projected needle surface area was multiplied by the factor 3.2 to determine the total needle surface area (Goisser et al., 2016).

Pre-dawn leaf water potential $\left(\Psi_{\mathrm{PD}}\right)$ and leaf osmotic potential $\left(\pi_{\mathrm{O}}\right)$ on fully sun-exposed twigs were determined on day $-6,2,7$, and 22 ( $n=6$, same trees used for $A_{\text {sat }}$, Tables S2 and S3). $\Psi_{\mathrm{PD}}$ was measured using a Scholander pressure bomb (mod. 1505D; PMS Instrument $\mathrm{Co}_{\mathrm{O}}$ ) before sunrise ( $3 \mathrm{am}-5 \mathrm{am} \mathrm{CET}$ ). $\pi_{\mathrm{O}}$ was determined with pressure volume curves (PV curves), following Tomasella et al. (2018). Collected twigs (two needle age classes) were rehydrated, and subsequently, their weight and water potential were repeatedly measured.

\subsection{0 | Statistical analysis}

We analyzed all data using $\mathrm{R}$ (version 4.0.3) in $\mathrm{R}$ studio (version 1.3.1093). The treatment effect on the CTR and the time lags were tested using a $t$ test. Beforehand, we tested the homogeneity of variances (F-test) and the normality of the data (Shapiro test). Since the homogeneity of variances between $C T R_{\text {above }}$ and $C T R_{\text {below }}$ was violated, we tested their difference with wilcox.test (package: stats, version: 3.6.1). The differences in $A_{\text {sat }}$, rates of stem/soil $\mathrm{CO}_{2}$ efflux, $\Psi_{\mathrm{PD}}$, and $\pi_{\mathrm{O}}$ were tested using a linear-mixed model (package: nlme, version: 3.1-151). We defined the treatment and day as fixed, and tree/chamber as random effects. Since $A_{\text {sat }}$, $\Psi_{\mathrm{PD}}$, and $\pi_{\mathrm{O}}$ were also measured in other plots, the plot was defined as a random effect. For every model, we tested the homogeneity of variances (Levene test) and the normality of the residuals (Shapiro test). If any fixed factor was significant, we performed a post-hoc test with Tukey correction (package: Ismeans, version: 2.30-0). The correlation between $\pi_{\mathrm{O}}$ and $\Psi_{\mathrm{PD}}$ was fitted with the following sigmoid curve.

$$
\pi_{\mathrm{O}}=d+\frac{a-d}{1+\mathrm{e}^{\frac{\Psi_{P D}-c}{b}}},
$$

where $a$ represents the start value of $\pi_{0}$ before watering, $b$ the slope coefficient of the regression, $c$ the instant of the regression inflection point, and $d$ the end value of $\pi_{\mathrm{O}}$.

\section{3 | RESULTS}

\subsection{Aboveground transport rates $\left(\mathrm{CTR}_{\text {above }}\right)$ from crown to trunk base}

The ${ }^{13} \mathrm{C}$-depleted $\mathrm{CO}_{2}$ was successfully taken up by tree crowns and transported downwards along the stem after the start of labeling. For example, $\delta^{13} \mathrm{C}_{\text {stem }}$ of one $\mathrm{CO}$ tree in Figure $4 \mathrm{a}$ was $-26.1 \pm 0.1 \%$ before the start of labeling and remained almost constant for 4 days after the start of labeling. Then, $\delta^{13} \mathrm{C}_{\text {stem }}$ suddenly decreased after the ${ }^{13} \mathrm{C}$-depleted tracer arrived. Similar courses of $\delta^{13} \mathrm{C}_{\text {stem }}$ were observed in all six labeled trees assessed in this study (Figure 4b; Figure S4). Despite similar transport distance of $28.4 \pm 0.3$ and $27.0 \pm 0.9 \mathrm{~m}$ in CO and TE trees, respectively (Table $\mathrm{S} 1$ ), the arrival of the ${ }^{13} \mathrm{C}$-depleted tracer in stem $\mathrm{CO}_{2}$ efflux was significantly delayed in TE trees compared to CO trees $(p<.05)$. The ${ }^{13} \mathrm{C}$-depleted tracer was found in stem $\mathrm{CO}_{2}$ efflux of $\mathrm{CO}$ trees $95 \pm 10 \mathrm{~h}$ after the start of labeling and watering, whereas in TE

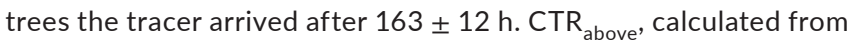
these arrival times, was $0.16 \pm 0.01 \mathrm{~m} \mathrm{~h}^{-1}$ and thus about half in TE spruce compared to $\mathrm{CO}$ spruce with $0.30 \pm 0.06 \mathrm{~m} \mathrm{~h}^{-1}$ (Figure $5 \mathrm{a}$; $p=.06)$. Already 2 weeks after watering, CTR $_{\text {above }}$ determined with the arrival of unlabeled tracer did not differ between treatments anymore, because of a significant increase in $\mathrm{CTR}_{\text {above }}$ of TE trees to $0.39 \pm 0.13 \mathrm{~m} \mathrm{~h}^{-1}$ (Figure $5 \mathrm{~b}$ ). $\mathrm{CTR}_{\text {above }}$ of $\mathrm{CO}$ trees remained almost constant during the study period $\left(0.32 \pm 0.05 \mathrm{~m} \mathrm{~h}^{-1} 2\right.$ weeks after watering).

\subsection{Leaf osmotic potential $\left(\pi_{0}\right)$ and predawn water potential $\left(\Psi_{\mathrm{PD}}\right)$}

$\pi_{\mathrm{O}}$ increased with $\Psi_{\mathrm{PD}}$ following asigmodal fit(Figure 6; $p<.001$ ). Before watering, $\Psi_{\mathrm{PD}}$ of the TE trees was on average $-0.93 \pm 0.03 \mathrm{MPa}$, which was significantly lower than that of $\mathrm{CO}$ trees with $-0.59 \pm 0.02 \mathrm{MPa}$ ( $p$ <.05). On day 7, $\Psi_{\mathrm{PD}}$ was then similar between treatments with $-0.61 \pm 0.02$ and $-0.69 \pm 0.05 \mathrm{MPa}$ in $\mathrm{CO}$ and TE trees, respectively $\left(p>\right.$.6). The lowest $\pi_{\mathrm{O}}$ of $-2.44 \pm 0.05 \mathrm{MPa}$ was observed for TE trees before watering, which was significantly lower than in CO trees with $-1.67 \pm 0.04 \mathrm{MPa}(p<.01)$. Correlated with $\Psi_{\mathrm{PD}}, \pi_{\mathrm{O}}$ of TE trees increased by $0.5 \mathrm{MPa}$ until day 22 to $-2.00 \pm 0.04 \mathrm{MPa}$. Nevertheless, on day $22, \pi_{\mathrm{O}}$ of TE trees was still somewhat lower than in CO trees $(p<.1)$ that stayed around $-1.6 \mathrm{MPa}$ throughout the study.

\section{3 | Belowground transport rates ( $\left.\mathrm{CTR}_{\text {below }}\right)$ from trunk base to soil $\mathrm{CO}_{2}$ efflux}

The labeling with ${ }^{13} \mathrm{C}$-depleted $\mathrm{CO}_{2}$ also caused a sudden decrease in $\delta^{13} \mathrm{C}_{\text {soil }}$, but with a smaller shift compared to $\delta^{13} \mathrm{C}_{\text {stem }}$ (Figure $4 \mathrm{c}, \mathrm{d}$ ). In the first week after watering, the ${ }^{13} \mathrm{C}$-depleted tracer was detected in soil $\mathrm{CO}_{2}$ efflux under $\mathrm{CO}$ trees $73 \pm 22 \mathrm{~h}$ 
First week after watering

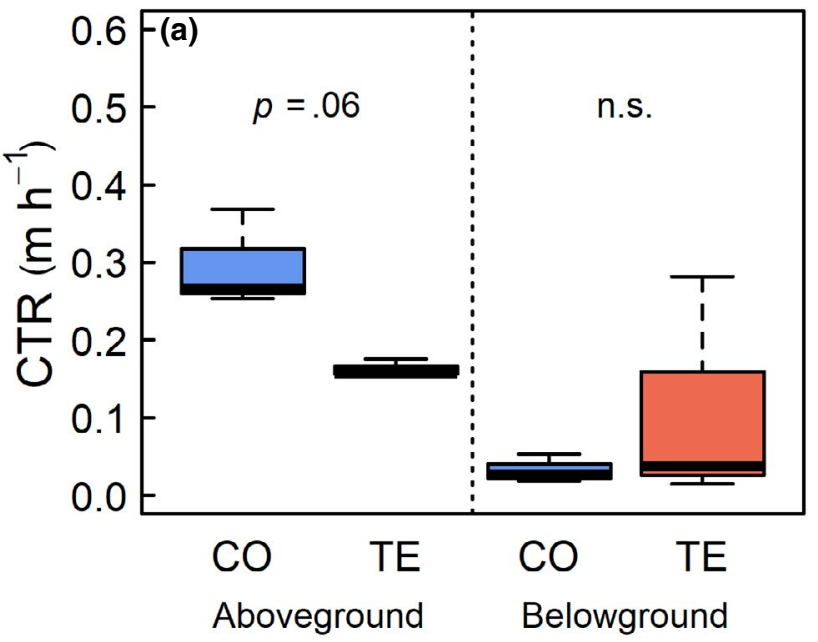

Two weeks after

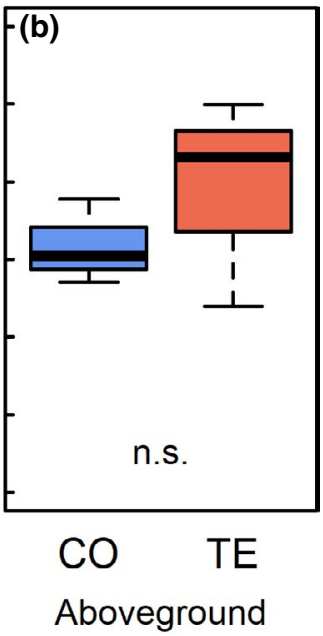

FIGURE 5 (a) Aboveground and belowground carbon transport rates (CTR) in the first week after watering determined by the arrival

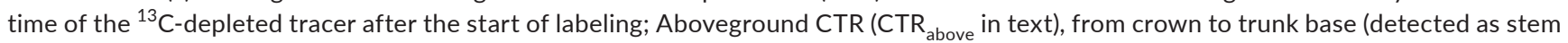
$\mathrm{CO}_{2}$ efflux); belowground CTR (CTR arrival time of the unlabeled tracer in stem $\mathrm{CO}_{2}$ efflux after the end of labeling. $p$-value and n.s. (no significance) give the results of $t$ tests comparing $\mathrm{CO}$ (control) and TE (previously drought-stressed, throughfall exclusion) trees

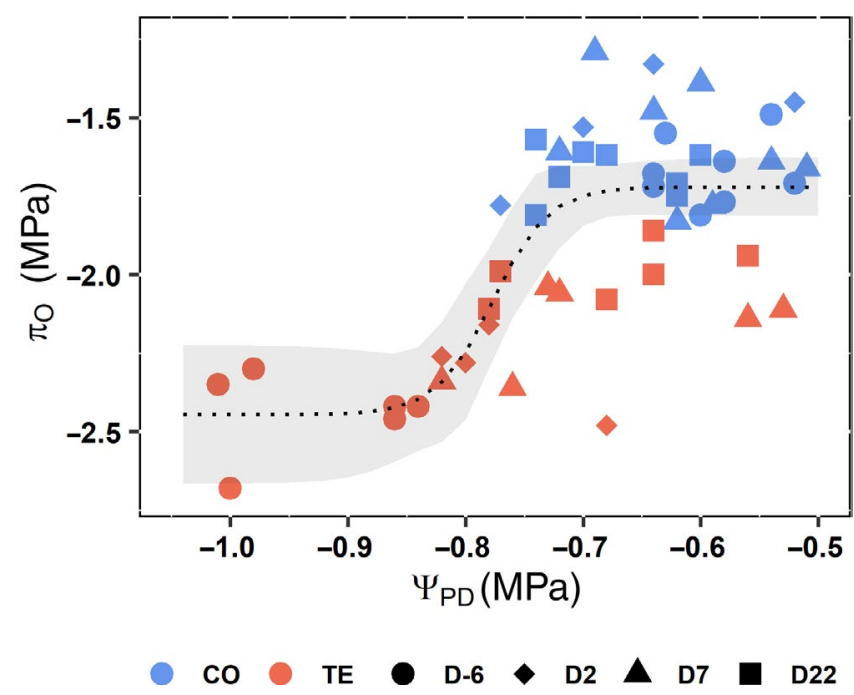

FIGURE 6 Correlation between leaf osmotic potential $\left(\pi_{\mathrm{O}}\right)$ and predawn leaf water potential $\left(\Psi_{\mathrm{PD}}\right)$ of control $(\mathrm{CO}$, blue $)$ and previously drought-stressed trees (throughfall exclusion, TE, red). Circles show the measurements 6 days before watering, diamonds on day 2 ( 2 days after watering), triangles on day 7 , and rectangles on day 22. The dotted curve displays the prediction of the sigmoid curve (all points were fitted together). The gray area gives the $95 \%$ confidence interval

after the detection in the stem $\mathrm{CO}_{2}$ efflux. The time lag was similar in TE trees with $62 \pm 37 \mathrm{~h}\left(p>\right.$.8). CTR $\mathrm{B}_{\text {below}}$, calculated from these time lags, was not significantly different between $\mathrm{CO}$ and TE trees with $0.03 \pm 0.01$ and $0.11 \pm 0.08 \mathrm{~m} \mathrm{~h}^{-1}$, respectively (Figure 5a, $p>$.7). The large variance of TE trees was caused by one tree with a high $\mathrm{CTR}_{\text {below }}\left(0.28 \mathrm{~m} \mathrm{~h}^{-1}\right)$. CTR $\mathrm{R}_{\text {below }}$ was significantly lower than $\operatorname{CTR}_{\text {above }}(p<.05)$.
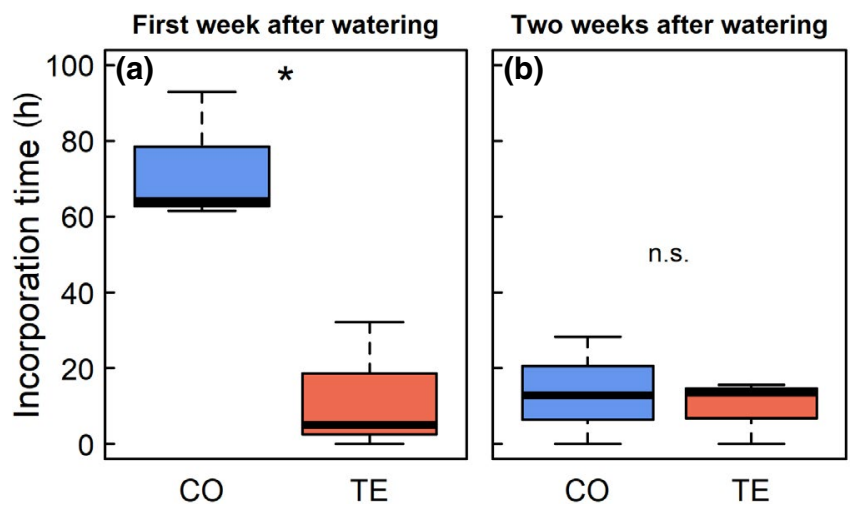

FIGURE 7 Incorporation time of current photoassimilates in living root tips (time lag between the arrival time at trunk base and arrival time in living root tips), (a) in the first week after watering, determined with the ${ }^{13} \mathrm{C}$-depleted tracer after the start of labeling, and (b) 2 weeks after watering, determined with the unlabeled tracer after the end of labeling. Asterisk $(p<.05)$ and n.s. (no significance) give the results of $t$ tests comparing $\mathrm{CO}$ (control) and TE (previously drought-stressed, throughfall exclusion) trees

\subsection{Incorporation of current photoassimilates in living fine roots}

In the first week after watering, the ${ }^{13} \mathrm{C}$-depleted tracer was detected in the living root tips of TE trees within $12 \pm 10 \mathrm{~h}$ after the detection in the stem $\mathrm{CO}_{2}$ efflux, whereas $\mathrm{CO}$ trees incorporated the current photoassimilates much later, that is, within $73 \pm 10 \mathrm{~h}$ ( $p<.05$; Figure 7a). Two weeks after watering, the incorporation time of the unlabeled tracer significantly decreased in $\mathrm{CO}$ trees to $14 \pm 8 \mathrm{~h}$ after the detection at the trunk base $(p<.05)$, which was similar to that of TE trees $(10 \pm 5 h, p>.7$; Figure $7 b)$. 
TABLE 1 Light-saturated $\mathrm{CO}_{2}$ assimilation rates $\left(A_{\text {sat }}\right)$ before (around day -14 ) and after (day 4 and 14) the watering (means \pm SE, $n=6$, expressed on the basis of total needle area), and rates of stem and soil $\mathrm{CO}_{2}$ efflux before (day -1) and after (day 4 and 14/15) watering (means $\pm \mathrm{SE}, n=3$ ) in $\mathrm{CO}$ (control) and TE (previously drought-stressed, throughfall exclusion) trees. The lowercase letters indicate the significant differences among treatments and days, determined by a post-hoc test after applying a linear-mixed model. $A_{\text {sat }}$, stem $\mathrm{CO}_{2}$ efflux, and soil $\mathrm{CO}_{2}$ efflux were tested separately

\begin{tabular}{lcll} 
& \multicolumn{1}{c}{ Before } & Day 4 & $\begin{array}{l}\text { Day } \\
14 / 15\end{array}$ \\
$\mathrm{~A}_{\text {sat }}\left(\mu \mathrm{mol} \mathrm{CO}_{2} \mathrm{~m}^{-2} \mathrm{~s}^{-1}\right)$ & & \\
$\mathrm{CO}$ & $2.7 \pm 0.2^{\mathrm{a}}$ & $2.6 \pm 0.3^{\mathrm{a}}$ & $2.3 \pm 0.3^{\mathrm{a}}$ \\
$\mathrm{TE}$ & $2.1 \pm 0.3^{\mathrm{a}}$ & $2.4 \pm 0.3^{\mathrm{a}}$ & $2.1 \pm 0.2^{\mathrm{a}}$ \\
Stem CO${ }_{2}$ efflux $\left(\mu \mathrm{mol} \mathrm{CO} \mathrm{m}^{-2} \mathrm{~s}^{-1}\right)$ & & \\
$\mathrm{CO}$ & $2.8 \pm 0.8^{\mathrm{a}}$ & $2.9 \pm 0.7^{\mathrm{a}}$ & $3.3 \pm 0.8^{\mathrm{a}}$ \\
$\mathrm{TE}$ & $3.3 \pm 0.7^{\mathrm{a}}$ & $2.8 \pm 0.2^{\mathrm{a}}$ & $3.3 \pm 0.6^{\mathrm{a}}$ \\
Soil CO${ }_{2}$ efflux $\left(\mu \mathrm{mol} \mathrm{CO} \mathrm{m}^{-2} \mathrm{~s}^{-1}\right)$ & & \\
$\mathrm{CO}$ & $6.7 \pm 0.4^{\mathrm{a}}$ & $5.4 \pm 0.3^{\mathrm{b}}$ & $6.6 \pm 0.4^{\mathrm{a}}$ \\
$\mathrm{TE}$ & $1.7 \pm 0.1^{\mathrm{c}}$ & $1.8 \pm 0.1^{\mathrm{c}}$ & $2.1 \pm 0.2^{\mathrm{c}}$ \\
\hline
\end{tabular}

\section{5 | Changes in C source/sink relations upon watering}

Before watering, light-saturated $\mathrm{CO}_{2}$ assimilation rates $\left(A_{\text {sat }}\right)$ were $2.7 \pm 0.2 \mu \mathrm{mol} \mathrm{m} \mathrm{m}^{-2} \mathrm{~s}^{-1}$ and thus hardly higher in CO compared to TE spruce with $2.1 \pm 0.3 \mu \mathrm{mol} \mathrm{m} \mathrm{m}^{-2} \mathrm{~s}^{-1}$ (Table 1; $p>$.6). Watering did not significantly affect the $A_{\text {sat }}$ of TE spruce, which remained almost constant under both treatments until day 14 (on day 4: $\mathrm{CO}, 2.6 \pm 0.3$; $\mathrm{TE}, 2.4 \pm 0.3$; on day 14: CO, $2.3 \pm 0.3$; TE, $2.1 \pm 0.2 \mu \mathrm{mol} \mathrm{m}^{-2} \mathrm{~s}^{-1}$ ).

Similarly, the rates of stem $\mathrm{CO}_{2}$ efflux did not significantly differ between treatments before watering (Table $1 ; p>.9$ ), although the $\mathrm{CO}_{2}$ efflux was slightly higher in TE with $3.3 \pm 0.7 \mu \mathrm{mol} \mathrm{m}{ }^{-2} \mathrm{~s}^{-1} \mathrm{com}-$ pared to $\mathrm{CO}$ spruce with $2.8 \pm 0.8 \mu \mathrm{mol} \mathrm{m} \mathrm{m}^{-2} \mathrm{~s}^{-1}$. Upon watering, the stem $\mathrm{CO}_{2}$ efflux rates remained almost constant with $2.9 \pm 0.7$ and $3.3 \pm 0.8$ in $\mathrm{CO}$, and $2.8 \pm 0.2$ and $3.3 \pm 0.6 \mu \mathrm{mol} \mathrm{m}^{-2} \mathrm{~s}^{-1}$ in TE trees on days 4 and 14.

Before watering, rates of soil $\mathrm{CO}_{2}$ efflux were $1.7 \pm 0.1$ $\mu \mathrm{mol} \mathrm{m}{ }^{-2} \mathrm{~s}^{-1}$ under TE trees, which were much lower than under CO trees with $6.7 \pm 0.4 \mu \mathrm{mol} \mathrm{m}{ }^{-2} \mathrm{~s}^{-1}\left(p<.01\right.$; Table 1). Soil $\mathrm{CO}_{2}$ efflux rates under TE trees around $2.0 \mu \mathrm{mol} \mathrm{m} \mathrm{m}^{-2} \mathrm{~s}^{-1}$ hardly increased after watering and remained significantly lower than those under $\mathrm{CO}$ trees with $5.4 \pm 0.3$ and $6.6 \pm 0.4 \mu \mathrm{mol} \mathrm{m} \mathrm{m}^{-2} \mathrm{~s}^{-1}$ on days 4 and 15 , respectively.

\section{DISCUSSION}

This study aims to elucidate the whole-tree $C$ transport in highly productive Norway spruce forests upon watering in a long-term climate-change experiment with repeated experimental summer droughts. In the last decades, Norway spruce forests have been showing immense dieback through severe drought (Arend et al., 2021; Boczoń et al., 2018; Hentschel et al., 2014; Rosner et al., 2016; Solberg, 2004). Also in our experimental site, we lost a couple of TE spruce trees during the drought period (Grams et al., 2021). In the present study, we ask whether surviving trees recover both the aboveground $\mathrm{C}$ transport, that is, from the crown to the trunk base, and the belowground $\mathrm{C}$ transport, that is, from the trunk base to the soil $\mathrm{CO}_{2}$ efflux after drought release. As the third transport process, we show how fast the current photoassimilates are incorporated in fine roots after drought release.

\subsection{Aboveground transport from crown to trunk base recovered within 2 weeks after drought release}

The observed CTR above $_{\text {of }}$ CO spruce (c. $0.30 \mathrm{~m} \mathrm{~h}^{-1}$ ) is somewhat higher than the average of gymnosperm trees calculated in a metaanalysis (0.22 $\mathrm{m} \mathrm{h}^{-1}$, Liesche et al., 2015), and corresponds to the values observed at the same site 10 years before (Kuptz et al., 2011). The repeated summer droughts restricted the $C T R_{\text {above }}$ of mature spruce. In the first week after drought release, the arrival of ${ }^{13} \mathrm{C}$ depleted tracer was still delayed by $2-3$ days in TE trees, indicating

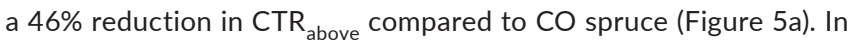
a counterpart experiment with pine trees growing on a naturally dry site (Gao et al., 2021), CTR from crown to rhizosphere doubled upon watering, similar to findings on mature spruce trees in the present study. This delay was likely to be caused by longer MRT of sugars in leaves (Dannoura et al., 2019; Epron et al., 2012; Hesse et al., 2019; Ruehr et al., 2009; Zang et al., 2014) and/or slower phloem transport (Hesse et al., 2019; Sevanto, 2014).

About 2 weeks after watering, CTR $\mathrm{Cbove}_{\text {of }}$ TE trees significantly increased to the level of CO trees, while CTR above of CO trees remained constant (Figure $5 \mathrm{~b}$ ). However, neither $\mathrm{C}$ source strength, that is, photosynthesis rates nor sink strength, assessed here as stem and soil $\mathrm{CO}_{2}$ efflux, significantly increased within the first 2 weeks after watering (Table 1). Likewise, unaffected soil $\mathrm{CO}_{2}$ efflux rates during 2 weeks after drought release were also observed in other Norway spruce forests, likely due to slow recovery of microbial activity (Muhr \& Borken, 2009; Schindlbacher et al., 2012). Considering that ratio of autotrophic (root-derived) to heterotrophic (microbial) soil respiration under the present spruce trees is known to decrease during drought (Nikolova et al., 2009), autotrophic respiration also likely remained low after drought release. Thus, changes of $\mathrm{C}$ source/sink relations are unlikely to

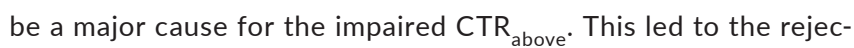
tion of $\mathrm{H} 1$ that $\mathrm{CTR}_{\text {above }}$ would recover with $\mathrm{C}$ source and/or sink strength, which is different from the study of Gao et al. (2021) on pine trees.

Although still not fully recovered to the rather constant level of $\mathrm{CO}$ trees, $\pi_{\mathrm{O}}$ of TE trees increased until day 22 after watering in parallel with $\Psi_{\mathrm{PD}}$ (Figure 6). This indicates a declined $C$ demand for osmotic adjustments, implying a decrease in leaf sugar concentration and MRT after drought release. Therefore, the delayed 
sugar export from leaves under drought was likely a component of slower $\mathrm{C}$ translocation from the crown to the trunk base. A quick recovery of MRT of sugars in leaves was also observed in beech saplings after drought release (Zang et al., 2014). In addition, since $\Psi_{\mathrm{PD}}$ of TE trees was significantly lower than that of $\mathrm{CO}$ trees before watering and increased to the control level by day 7 (Figure 6), increased phloem viscosity due to water limitation in the xylem might be another cause for the slower phloem transport under drought (Epron et al., 2016; Woodruff, 2014). In principle, CTR may be reduced by intensified leakage-retrieval of transported sugars in the phloem (van Bel, 2003; De Schepper et al., 2013; Epron et al., 2016), however, there is no evidence to date that this mechanism is enhanced under drought (Salmon et al., 2019). Considering the rapid increase in $C T R_{\text {above }}$ within 2 weeks, reduction in phloem conduit diameter is unlikely to have occurred, which is in line with unaffected branch phloem lumen area of the same TE spruce trees (Giai Petit, University of Padova, in preparation). Miller et al. (2020) also reported an unaffected sieve cell production of mature spruce under summer drought. Furthermore, phloem production of the present spruce likely peaked before watering under moderate water stress (c. $-0.9 \mathrm{MPa}$ ), since it has been found to peak before mid-June in spruce trees (Gričar et al., 2014; Jyske et al., 2015; Miller et al., 2020). This explains the different results on other tree species including conifers, which decreased phloem growth and diameter under more severe water stress (Dannoura et al., 2019; Woodruff, 2014).

It is important to note that the xylem water potential and to some extent also $\pi_{\mathrm{O}}$ were continuously increasing after watering until the ${ }^{13} \mathrm{C}$-depleted tracer arrived in stem $\mathrm{CO}_{2}$ efflux around day 7 in TE trees. Therefore, the drought-induced reduction in $\mathrm{CTR}_{\text {above }}$ might have been even more pronounced before the watering. Most importantly, the aboveground CTR from crown to trunk base of mature spruce fully recovered within 2 weeks after watering, hence showing high resilience to long-term and recurrent summer droughts.

\section{2 | Belowground transport from trunk base to soil $\mathrm{CO}_{2}$ efflux was similar between treatments already in the first week after watering}

The observed CTR $\mathrm{Bel}_{\text {bew }}$ of $\mathrm{CO}$ trees (c. $0.03 \mathrm{~m} \mathrm{~h}^{-1}$ ) was about 10

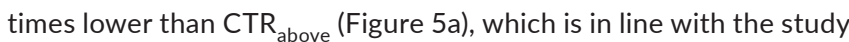
of Mencuccini and Hölttä (2010) reporting on a slower belowground transport compared to transport along the stem phloem. The variance of $\mathrm{CTR}_{\text {below }}$ in TE trees was high, likely due to the soil heterogeneities and unknown root structures from the trunk base to the spot of soil $\mathrm{CO}_{2}$ efflux assessments. Already in the first week after watering, $\mathrm{CTR}_{\text {below }}$ was similar between $\mathrm{CO}$ and TE trees. However conversely to our expectation, rates of soil $\mathrm{CO}_{2}$ efflux did not increase after watering (as discussed above), which led to the rejection of $\mathrm{H} 2$ that $\mathrm{CTR}_{\text {below }}$ would recover in parallel with increasing $C$ sink or source strength. Upon watering, water potential in leaves fully recovered within 1 week (Figure 6) and can be expected to have increased faster in roots in parallel with increasing soil water potential (Fiscus, 1972; Gleason et al., 2017; McCully, 1999). Therefore, we suggest a fast and full recovery of root phloem transport within few days, that is, even before the ${ }^{13} \mathrm{C}$-depleted tracer arrived at the trunk base (i.e., around day 7). Moreover, speed of soil $\mathrm{CO}_{2}$ diffusion was likely similar in soils of both treatments, as gas diffusion in soils is negatively correlated with soil water content (Kuzyakov \& Gavrichkova, 2010) that was very similar in TE and CO plots within few days after watering (Grams et al., 2021).

Since the distance of the aboveground transport is much longer than belowground in tall mature trees, particularly in shallow rooting spruce trees, the drought-reduced transport rates from crown to soil $\mathrm{CO}_{2}$ efflux are mainly caused by the restricted aboveground $\mathrm{C}$ transport from crown to trunk base. However, short young trees or deep rooting mature trees have higher ratio of belowground to total transport distance. Thus, the belowground $C$ transport from trunk base to soil $\mathrm{CO}_{2}$ efflux might play a significant role for the wholetree transport processes and forest $C$ cycling (Gao et al., 2021), since

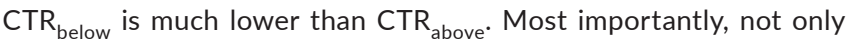
aboveground but the whole-tree CTR from crown to soil $\mathrm{CO}_{2}$ efflux showed a full recovery within 2 weeks after watering, hence indicating high resilience to long-term and recurrent summer droughts.

\subsection{Incorporation of current photoassimilates in fine roots was faster in trees recovering from drought than in control trees}

The ${ }^{13} \mathrm{C}$-depleted tracer was detected in living root tips of TE trees within $12 \mathrm{~h}$ after the arrival at the trunk base, but only $60 \mathrm{~h}$ later in $\mathrm{CO}$ trees (Figure 7a), confirming $\mathrm{H} 3$ that incorporation of current photoassimilates is faster in trees recovering from drought. The faster use of the tracers in living root tips of TE trees compared to controls coincided with the growth of new roots that started within few days after watering (personal observations on site), suggesting a higher $\mathrm{C}$ demand in fine roots of TE trees. However, the enhanced fine root growth upon watering in TE plots was not reflected in soil $\mathrm{CO}_{2}$ efflux, likely due to a small contribution of respiration of fine roots grown after watering to total soil $\mathrm{CO}_{2}$ efflux: that is, small biomass share of growing fine roots to total roots. Furthermore, Nikolova et al. (2020) found on the same spruce trees that respiration rates of fine roots and proportion of absorptive fine roots to the total root biomass were both small. A preferential investment of current photoassimilates following high $\mathrm{C}$ sink strength of growing fine roots has also been observed in young beech trees upon drought release (Hagedorn et al., 2016) and in naturally drought-stressed mature pine trees after a rainfall event (Gao et al., 2021; Joseph et al., 2020).

Not only previously drought-stressed spruce but also control trees responded with fast $\mathrm{C}$ incorporation in living fine roots after increase in soil water availability. During an intensive rain event on day 17 (following a short dry spell), fine root growth was likely induced in the shallow soil layers (Joseph et al., 2020; Meier \& Leuschner, 2008). This may explain the fast arrival of unlabeled tracer in root 
tips in both treatments 2 weeks after drought release (Figure 7b). Our results suggest, therefore, that the speed of incorporation of current photoassimilates in living root tips of mature spruce trees is strongly dependent on the $\mathrm{C}$ demand for root production, that is, "sink controlled" as suggested earlier (Fatichi et al., 2014; Gavito et al., 2019; Hagedorn et al., 2016; Körner, 2015). In contrast to previous studies (Gao et al., 2021; Hagedorn et al., 2016), the increased "sink demand" by stimulated fine root growth in mature spruce did not significantly affect the whole-tree CTR from crown to soil, since they were still reduced in the first week after drought release (Figure 5a). Above all, mature drought-stressed spruce trees respond to drought release by quickly supplying the growing root tips with current photoassimilates. In addition to the high resilience in whole-tree $\mathrm{C}$ transport, this response is essential to regenerate the water-absorbing root system.

\section{5 | CONCLUSION}

The present study reveals high resilience of the whole-tree $C$ transport system in Norway spruce forests even after recurrent summer droughts. Once spruce trees manage to survive drought periods, their whole-tree $C$ transport system may be expected to recover quickly after drought release. This ensures high resilience of $C$ supply with current photoassimilates, in particular to belowground sinks such as growing fine roots. Once the water-absorbing root system is restored, long-term recovery of $\mathrm{C}$ uptake and supply to further sinks can be expected. However, recovery of the $\mathrm{C}$ transport is only one of the many important prerequisites for the recovery of tree productivity. Thus, long-term observations of $\mathrm{C}$ source and sink activities upon drought release are necessary to elucidate the recovery potential of productivity in central European forests dominated by Norway spruce stands.

\section{ACKNOWLEDGMENTS}

We thank Thomas Feuerbach (TUM) for technical support and maintenance of the measurement equipment. We also thank Timo Gebhardt, Karl-Heinz Häberle, Josef Heckmair, Peter Kuba, bachelor/master students (TUM), Laura Pohlenz, Ramona Werner, and ecology volunteers (Helmholtz Zentrum München) for support during the fieldwork, Phillip Papastefanou (TUM) for support with the calculation of CTR, Timo Knüver (KIT) for his support with the soil respiration unit, and Manuela Laski and Manuela Oettli for laboratory support (both WSL). This study was funded by the German Research Foundation (DFG) through grants GR 1881/5-1, MA1763/10-1, PR555/2-1, PR292/22-1 and by the Bavarian State Ministries of the Environment and Consumer Protection as well as Food, Agriculture and Forestry (W047/Kroof II). RR and NKR were supported by the German Research Foundation through its Emmy Noether Program (RU 1657/2-1). MML was supported by the Ambizione grant (179978) from the Swiss National Science Foundation (SNSF). BDH was funded by a doctoral scholarship from the German Federal Environmental Foundation (DBU, AZ 20018/535). Open Access funding enabled and organized by Projekt DEAL.

\section{CONFLICT OF INTEREST}

The authors declare that there is no conflict of interest.

\section{AUTHOR CONTRIBUTIONS}

TEEG and KP designed the experiment. KH, VR, and TEEG prepared and conducted the ${ }^{13} \mathrm{C}$ labeling experiment. All authors contributed to the data collection. $\mathrm{KH}$ analyzed and interpreted the data with supports from TEEG, JD, and VR. KH wrote the manuscript with contributions of all authors.

\section{DATA AVAILABILITY STATEMENT}

The data that support the findings of this study are openly available in mediaTUM at https://doi.org/10.14459/2021mp1637391.

\section{ORCID}

Kyohsuke Hikino (D) https://orcid.org/0000-0002-6981-3988 Vincent P. Riedel (D) https://orcid.org/0000-0003-1685-8135 Romy Rehschuh (D) https://orcid.org/0000-0001-9140-0306 Nadine K. Ruehr (D) https://orcid.org/0000-0001-5989-7463 Benjamin D. Hesse (D) https://orcid.org/0000-0003-1113-9801 Marco M. Lehmann (D) https://orcid.org/0000-0003-2962-3351 Franz Buegger (D) https://orcid.org/0000-0003-3526-4711 Fabian Weikl (D) https://orcid.org/0000-0003-3973-6341 Karin Pritsch (D) https://orcid.org/0000-0001-6384-2473

Thorsten E. E. Grams (D) https://orcid.org/0000-0002-4355-8827

\section{REFERENCES}

Allen, C. D., Breshears, D. D., \& McDowell, N. G. (2015). On underestimation of global vulnerability to tree mortality and forest die-off from hotter drought in the Anthropocene. Ecosphere, 6(8), art129. https://doi.org/10.1890/ES15-00203.1

Allen, C. D., Macalady, A. K., Chenchouni, H., Bachelet, D., McDowell, N., Vennetier, M., Kitzberger, T., Rigling, A., Breshears, D. D., Hogg, E. H., Gonzalez, P., Fensham, R., Zhang, Z., Castro, J., Demidova, N., Lim, J.-H., Allard, G., Running, S. W., Semerci, A., \& Cobb, N. (2010). A global overview of drought and heat-induced tree mortality reveals emerging climate change risks for forests. Forest Ecology and Management, 259(4), 660-684. https://doi.org/10.1016/j. foreco.2009.09.001

Andersen, C. P., Ritter, W., Gregg, J., Matyssek, R., \& Grams, T. E. E. (2010). Below-ground carbon allocation in mature beech and spruce trees following long-term, experimentally enhanced $\mathrm{O} 3$ exposure in Southern Germany. Environmental Pollution, 158(8), 2604-2609. https://doi.org/10.1016/j.envpol.2010.05.008

Arend, M., Link, R. M., Patthey, R., Hoch, G., Schuldt, B., \& Kahmen, A. (2021). Rapid hydraulic collapse as cause of drought-induced mortality in conifers. Proceedings of the National Academy of Sciences of the United States of America, 118(16), e2025251118. https://doi. org/10.1073/pnas.2025251118

Barthel, M., Hammerle, A., Sturm, P., Baur, T., Gentsch, L., \& Knohl, A. (2011). The diel imprint of leaf metabolism on the $\delta^{13} \mathrm{C}$ signal of soil respiration under control and drought conditions. The New Phytologist, 192(4), 925-938. https://doi.org/10.1111/j.1469-8137. 2011.03848.x

Boczoń, A., Kowalska, A., Ksepko, M., \& Sokołowski, K. (2018). Climate warming and drought in the Bialowieza Forest from 1950-2015 and their impact on the dieback of Norway spruce stands. Water, 10(11), 1950-2015. https://doi.org/10.3390/w10111502 
Braden-Behrens, J., Yan, Y., \& Knohl, A. (2017). A new instrument for stable isotope measurements of ${ }^{13} \mathrm{C}$ and ${ }^{18} \mathrm{O}$ in $\mathrm{CO}_{2}$ - Instrument performance and ecological application of the Delta Ray IRIS analyzer. Atmospheric Measurement Techniques, 10(11), 4537-4560. https:// doi.org/10.5194/amt-10-4537-2017

Caudullo, G., Tinner, W., \& De Rigo, D. (2016). Picea abies in Europe: Distribution, habitat, usage and threats. In J. San-Miguel-Ayanz, D. de Rigo, G. Caudullo, T. Houston Durrant, \& A. Mauri (Eds.), European atlas of forest tree species (pp. 114-116). Publications Office of the EU, e012300+ pp.

Ciais, P. H., Reichstein, M., Viovy, N., Granier, A., Ogée, J., Allard, V., Aubinet, M., Buchmann, N., Bernhofer, C., Carrara, A., Chevallier, F., De Noblet, N., Friend, A. D., Friedlingstein, P., Grünwald, T., Heinesch, B., Keronen, P., Knohl, A., Krinner, G., ... Valentini, R. (2005). Europe-wide reduction in primary productivity caused by the heat and drought in 2003. Nature, 437(7058), 529-533. https:// doi.org/10.1038/nature03972

Collins, M., Knutti, R., Arblaster, J., Dufresne, J.-L., Fichefet, T., Friedlingstein, P., Gao, X., Gutowski, W. J., Johns, T., Krinner, G., Shongwe, M., Tebaldi, C., Weaver, A. J., \& Wehner, M. (2013). Longterm climate change: Projections, commitments and irreversibility. In T. F. Stocker, D. Qin, G.-K. Plattner, M. Tignor, S. K. Allen, J. Boschung, A. Nauels, Y. Xia, V. Bex, \& P. M. Midgley (Eds.), Climate change 2013: The physical science basis. Contribution of working group I to the fifth assessment report of the Intergovernmental Panel on Climate Change (pp. 1029-1136). Cambridge University Press.

Dannoura, M., Epron, D., Desalme, D., Massonnet, C., Tsuji, S., Plain, C., Priault, P., \& Gérant, D. (2019). The impact of prolonged drought on phloem anatomy and phloem transport in young beech trees. Tree Physiology, 39(2), 201-210. https://doi.org/10.1093/treephys/ tpy070

Dawson, T. E., Mambelli, S., Plamboeck, A. H., Templer, P. H., \& Tu, K. P. (2002). Stable isotopes in plant ecology. Annual Review of Ecology and Systematics, 33(1), 507-559. https://doi.org/10.1146/annur ev.ecolsys.33.020602.095451

De Schepper, V., De Swaef, T., Bauweraerts, I., \& Steppe, K. (2013). Phloem transport: A review of mechanisms and controls. Journal of Experimental Botany, 64(16), 4839-4850. https://doi.org/10.1093/ jxb/ert302

Epron, D., Bahn, M., Derrien, D., Lattanzi, F. A., Pumpanen, J., Gessler, A., Högberg, P., Maillard, P., Dannoura, M., Gérant, D., \& Buchmann, N. (2012). Pulse-labelling trees to study carbon allocation dynamics: A review of methods, current knowledge and future prospects. Tree Physiology, 32(6), 776-798. https://doi.org/10.1093/treephys/ tps057

Epron, D., Cabral, O. M. R., Laclau, J.-P., Dannoura, M., Packer, A. P., Plain, C., Battie-Laclau, P., Moreira, M. Z., Trivelin, P. C. O., Bouillet, J.-P., Gérant, D., \& Nouvellon, Y. (2016). In situ ${ }^{13} \mathrm{CO}_{2}$ pulse labelling of field-grown eucalypt trees revealed the effects of potassium nutrition and throughfall exclusion on phloem transport of photosynthetic carbon. Tree Physiology, 36(1), 6-21. https://doi.org/10.1093/ treephys/tpv090

Epron, D., \& Dreyer, E. (1996). Starch and soluble carbohydrates in leaves of water-stressed oak saplings. Annales Des Sciences Forestières, 53(2-3), 263-268. https://doi.org/10.1051/forest:19960209

Fatichi, S., Leuzinger, S., \& Körner, C. (2014). Moving beyond photosynthesis: From carbon source to sink-driven vegetation modeling. The New Phytologist, 201(4), 1086-1095. https://doi.org/10.1111/ nph.12614

Fiscus, E. L. (1972). In situ measurement of root-water potential. Plant Physiology, 50(1), 191-193. https://doi.org/10.1104/pp.50.1.191

Gamnitzer, U., Schäufele, R., \& Schnyder, H. (2009). Observing ${ }^{13} \mathrm{C}$ labelling kinetics in $\mathrm{CO}_{2}$ respired by a temperate grassland ecosystem. The New Phytologist, 184(2), 376-386. https://doi. org/10.1111/j.1469-8137.2009.02963.x
Gao, D., Joseph, J., Werner, R. A., Brunner, I., Zürcher, A., Hug, C., Wang, A., Zhao, C., Bai, E., Meusburger, K., Gessler, A., \& Hagedorn, F. (2021). Drought alters the carbon footprint of trees in soilstracking the spatio-temporal fate of ${ }^{13} \mathrm{C}$-labelled assimilates in the soil of an old-growth pine forest. Global Change Biology. https://doi. org/10.1111/gcb.15557

Gavito, M. E., Jakobsen, I., Mikkelsen, T. N., \& Mora, F. (2019). Direct evidence for modulation of photosynthesis by an arbuscular mycorrhiza-induced carbon sink strength. The New Phytologist, 223(2), 896-907. https://doi.org/10.1111/nph.15806

Gleason, S. M., Wiggans, D. R., Bliss, C. A., Young, J. S., Cooper, M., Willi, K. R., \& Comas, L. H. (2017). Embolized stems recover overnight in Zea mays: The role of soil water, root pressure, and nighttime transpiration. Frontiers in Plant Science, 8, 662. https://doi.org/10.3389/ fpls.2017.00662

Goisser, M., Geppert, U., Rötzer, T., Paya, A., Huber, A., Kerner, R., Bauerle, T., Pretzsch, H., Pritsch, K., Häberle, K. H., Matyssek, R., \& Grams, T. (2016). Does belowground interaction with Fagus sylvatica increase drought susceptibility of photosynthesis and stem growth in Picea abies? Forest Ecology and Management, 375, 268278. https://doi.org/10.1016/j.foreco.2016.05.032

Grams, T. E. E., Hesse, B. D., Gebhardt, T., Weikl, F., Rötzer, T., Kovacs, B., Hikino, K., Hafner, B. D., Brunn, M., Bauerle, T. L., Häberle, K.-H., Pretzsch, H., \& Pritsch, K. (2021). The Kroof experiment: Realization and efficacy of a recurrent drought experiment plus recovery in a beech/spruce forest. Ecosphere, 12(3). https://doi. org/10.1002/ecs2.3399

Grams, T. E. E., Werner, H., Kuptz, D., Ritter, W., Fleischmann, F., Andersen, C. P., \& Matyssek, R. (2011). A free-air system for longterm stable carbon isotope labeling of adult forest trees. Trees, 25(2), 187-198. https://doi.org/10.1007/s00468-010-0497-7

Gričar, J., Prislan, P., Gryc, V., Vavrčík, H., de Luis, M., \& Cufar, K. (2014). Plastic and locally adapted phenology in cambial seasonality and production of xylem and phloem cells in Picea abies from temperate environments. Tree Physiology, 34(8), 869-881. https://doi. org/10.1093/treephys/tpu026

Hagedorn, F., Joseph, J., Peter, M., Luster, J., Pritsch, K., Geppert, U., Kerner, R., Molinier, V., Egli, S., Schaub, M., Liu, J.-F., Li, M., Sever, K., Weiler, M., Siegwolf, R. T. W., Gessler, A., \& Arend, M. (2016). Recovery of trees from drought depends on belowground sink control. Nature Plants, 2, 16111. https://doi.org/10.1038/NPLAN TS.2016.111

Hartmann, H., Ziegler, W., Kolle, O., \& Trumbore, S. (2013). Thirst beats hunger - Declining hydration during drought prevents carbon starvation in Norway spruce saplings. The New Phytologist, 200(2), 340-349. https://doi.org/10.1111/nph.12331

Hartmann, H., Ziegler, W., \& Trumbore, S. (2013). Lethal drought leads to reduction in nonstructural carbohydrates in Norway spruce tree roots but not in the canopy. Functional Ecology, 27(2), 413-427. https://doi.org/10.1111/1365-2435.12046

Hentschel, R., Rosner, S., Kayler, Z. E., Andreassen, K., Børja, I., Solberg, S., Tveito, O. E., Priesack, E., \& Gessler, A. (2014). Norway spruce physiological and anatomical predisposition to dieback. Forest Ecology and Management, 322, 27-36. https://doi.org/10.1016/j. foreco.2014.03.007

Hesse, B. D., Goisser, M., Hartmann, H., \& Grams, T. E. E. (2019). Repeated summer drought delays sugar export from the leaf and impairs phloem transport in mature beech. Tree Physiology, 39(2), 192-200. https://doi.org/10.1093/treephys/tpy122

Hölttä, T., Mencuccini, M., \& Nikinmaa, E. (2009). Linking phloem function to structure: Analysis with a coupled xylem-phloem transport model. Journal of Theoretical Biology, 259(2), 325-337. https://doi. org/10.1016/j.jtbi.2009.03.039

Hölttä, T., Vesala, T., Sevanto, S., Perämäki, M., \& Nikinmaa, E. (2006). Modeling xylem and phloem water flows in trees according to 
cohesion theory and Münch hypothesis. Trees, 20(1), 67-78. https:// doi.org/10.1007/s00468-005-0014-6

Hsiao, T. C. (1973). Plant responses to water stress. Annual Review of Plant Physiology, 24(1), 519-570. https://doi.org/10.1146/annur ev.pp.24.060173.002511

IPCC. (2007). Summary for policymakers. In M. L. Parry, O. F. Canziani, J. P. Palutikof, P. J. van der Linden, \& C. E. Hanson (Eds.), Climate change 2007: Impacts, adaptation and vulnerability. Contribution of working group II to the fourth assessment report of the intergovernmental panel on climate change (pp. 7-22). Cambridge University Press.

IPCC. (2014). Climate change 2014: Synthesis report. Contribution of working groups I, II and III to the fifth assessment report of the intergovernmental panel on climate change [Core Writing Team, R. K. Pachauri, \& L. A. Meyer (Eds.)]. IPCC, $151 \mathrm{pp}$.

Joseph, J., Gao, D., Backes, B., Bloch, C., Brunner, I., Gleixner, G., Haeni, M., Hartmann, H., Hoch, G., Hug, C., Kahmen, A., Lehmann, M. M., Li, M.-H., Luster, J., Peter, M., Poll, C., Rigling, A., Rissanen, K. A., Ruehr, N. K., ... Gessler, A. (2020). Rhizosphere activity in an oldgrowth forest reacts rapidly to changes in soil moisture and shapes whole-tree carbon allocation. Proceedings of the National Academy of Sciences of the United States of America, 117(40), 24885-24892. https://doi.org/10.1073/pnas.2014084117

Jyske, T. M., Suuronen, J.-P., Pranovich, A. V., Laakso, T., Watanabe, U., Kuroda, K., \& Abe, H. (2015). Seasonal variation in formation, structure, and chemical properties of phloem in Picea abies as studied by novel microtechniques. Planta, 242(3), 613-629. https://doi. org/10.1007/s00425-015-2347-8

Keeling, C. D. (1958). The concentration and isotopic abundances of atmospheric carbon dioxide in rural areas. Geochimica Et Cosmochimica Acta, 13(4), 322-334. https://doi.org/10.1016/00167037(58)90033-4

Keeling, C. D. (1961). The concentration and isotopic abundances of carbon dioxide in rural and marine air. Geochimica Et Cosmochimica Acta 24(3-4), 277-298. https://doi.org/10.1016/0016-7037(61)90023-0

Kodama, N., Barnard, R. L., Salmon, Y., Weston, C., Ferrio, J. P., Holst, J., Werner, R. A., Saurer, M., Rennenberg, H., Buchmann, N., \& Gessler, A. (2008). Temporal dynamics of the carbon isotope composition in a Pinus sylvestris stand: From newly assimilated organic carbon to respired carbon dioxide. Oecologia, 156(4), 737-750. https://doi. org/10.1007/s00442-008-1030-1

Körner, C. (2015). Paradigm shift in plant growth control. Current Opinion in Plant Biology, 25, 107-114. https://doi.org/10.1016/j. pbi.2015.05.003

Kuptz, D., Fleischmann, F., Matyssek, R., \& Grams, T. E. E. (2011). Seasonal patterns of carbon allocation to respiratory pools in 60-yr-old deciduous (Fagus sylvatica) and evergreen (Picea abies) trees assessed via whole-tree stable carbon isotope labeling. The New Phytologist 191(1), 160-172. https://doi.org/10.1111/j.1469-8137.2011.03676.x

Kuzyakov, Y., \& Gavrichkova, O. (2010). REVIEW: Time lag between photosynthesis and carbon dioxide efflux from soil: A review of mechanisms and controls. Global Change Biology, 16(12), 3386-3406. https://doi.org/10.1111/j.1365-2486.2010.02179.x

Lehmann, M. M., Egli, M., Brinkmann, N., Werner, R. A., Saurer, M., \& Kahmen, A. (2020). Improving the extraction and purification of leaf and phloem sugars for oxygen isotope analyses. Rapid Communications in Mass Spectrometry, 34(19), e8854. https://doi. org/10.1002/rcm.8854

Lemoine, R., La Camera, S., Atanassova, R., Dédaldéchamp, F., Allario, T., Pourtau, N., Bonnemain, J.-L., Laloi, M., Coutos-Thévenot, P., Maurousset, L., Faucher, M., Girousse, C., Lemonnier, P., Parrilla, J., \& Durand, M. (2013). Source-to-sink transport of sugar and regulation by environmental factors. Frontiers in Plant Science, 4, 272. https://doi.org/10.3389/fpls.2013.00272

Liesche, J., Windt, C., Bohr, T., Schulz, A., \& Jensen, K. H. (2015). Slower phloem transport in gymnosperm trees can be attributed to higher sieve element resistance. Tree Physiology, 35(4), 376-386. https:// doi.org/10.1093/treephys/tpv020

Lloret, F., Keeling, E. G., \& Sala, A. (2011). Components of tree resilience: Effects of successive low-growth episodes in old ponderosa pine forests. Oikos, 120(12), 1909-1920. https://doi. org/10.1111/j.1600-0706.2011.19372.x

McCully. (1999). Root xylem embolisms and refilling. Relation To water potentials of soil, roots, and leaves, and osmotic potentials of root xylem Sap. Plant Physiology, 119(3), 1001-1008. https://doi. org/10.1104/pp.119.3.1001

McDowell, N., Pockman, W. T., Allen, C. D., Breshears, D. D., Cobb, N., Kolb, T., Plaut, J., Sperry, J., West, A., Williams, D. G., \& Yepez, E. A. (2008). Mechanisms of plant survival and mortality during drought: Why do some plants survive while others succumb to drought? The New Phytologist, 178(4), 719-739. https://doi. org/10.1111/j.1469-8137.2008.02436.x

Meier, I. C., \& Leuschner, C. (2008). Belowground drought response of European beech: Fine root biomass and carbon partitioning in 14 mature stands across a precipitation gradient. Global Change Biology, 14(9), 2081-2095. https://doi.org/10.1111/j.1365-2486. 2008.01634.x

Mencuccini, M., \& Hölttä, T. (2010). The significance of phloem transport for the speed with which canopy photosynthesis and belowground respiration are linked. The New Phytologist, 185(1), 189-203. https://doi.org/10.1111/j.1469-8137.2009.03050.x

Miller, T. W., Stangler, D. F., Larysch, E., Seifert, T., Spiecker, H., \& Kahle, H.-P. (2020). Plasticity of seasonal xylem and phloem production of Norway spruce along an elevational gradient. Trees, 34(5), 12811297. https://doi.org/10.1007/s00468-020-01997-6

Muhr, J., \& Borken, W. (2009). Delayed recovery of soil respiration after wetting of dry soil further reduces $C$ losses from a Norway spruce forest soil. Journal of Geophysical Research, 114(G4). https://doi. org/10.1029/2009JG000998

Nikolova, P. S., Bauerle, T. L., Häberle, K.-H., Blaschke, H., Brunner, I., \& Matyssek, R. (2020). Fine-root traits reveal contrasting ecological strategies in European beech and Norway spruce during extreme drought. Frontiers in Plant Science, 11, 1211. https://doi. org/10.3389/fpls.2020.01211

Nikolova, P. S., Raspe, S., Andersen, C. P., Mainiero, R., Blaschke, H., Matyssek, R., \& Häberle, K.-H. (2009). Effects of the extreme drought in 2003 on soil respiration in a mixed forest. European Journal of Forest Research, 128(2), 87-98. https://doi.org/10.1007/ s10342-008-0218-6

Pretzsch, H., Grams, T. E. E., Häberle, K.-H., Pritsch, K., Bauerle, T. L., \& Rötzer, T. (2020). Growth and mortality of Norway spruce and European beech in monospecific and mixed-species stands under natural episodic and experimentally extended drought. Results of the KROOF throughfall exclusion experiment. Trees, 34(4), 957970. https://doi.org/10.1007/s00468-020-01973-0

Pretzsch, H., Rötzer, T., Matyssek, R., Grams, T. E. E., Häberle, K.-H., Pritsch, K., Kerner, R., \& Munch, J.-C. (2014). Mixed Norway spruce (Picea abies [L.] Karst) and European beech (Fagus sylvatica [L.] stands under drought: From reaction pattern to mechanism. Trees, 28(5), 1305-1321. https://doi.org/10.1007/s0046 8-014-1035-9

Rosner, S., Světlík, J., Andreassen, K., Børja, I., Dalsgaard, L., Evans, R., Luss, S., Tveito, O. E., \& Solberg, S. (2016). Novel hydraulic vulnerability proxies for a boreal conifer species reveal that opportunists may have lower survival prospects under extreme climatic events. Frontiers in Plant Science, 7, 831. https://doi.org/10.3389/ fpls.2016.00831

Ruehr, N. K., Grote, R., Mayr, S., \& Arneth, A. (2019). Beyond the extreme: Recovery of carbon and water relations in woody plants following heat and drought stress. Tree Physiology, 39(8), 1285-1299. https://doi.org/10.1093/treephys/tpz032 
Ruehr, N. K., Offermann, C. A., Gessler, A., Winkler, J. B., Ferrio, J. P., Buchmann, N., \& Barnard, R. L. (2009). Drought effects on allocation of recent carbon: From beech leaves to soil $\mathrm{CO}_{2}$ efflux. The New Phytologist, 184(4), 950-961. https://doi.org/10.1111/j.1469-8137.2009.03044.x

Ryan, M. G., \& Asao, S. (2014). Phloem transport in trees. Tree Physiology, 34(1), 1-4. https://doi.org/10.1093/treephys/tpt123

Salmon, Y., Dietrich, L., Sevanto, S., Hölttä, T., Dannoura, M., \& Epron, D. (2019). Drought impacts on tree phloem: From cell-level responses to ecological significance. Tree Physiology, 39(2), 173-191. https:// doi.org/10.1093/treephys/tpy153

Schindlbacher, A., Wunderlich, S., Borken, W., Kitzler, B., ZechmeisterBoltenstern, S., \& Jandl, R. (2012). Soil respiration under climate change: Prolonged summer drought offsets soil warming effects. Global Change Biology, 18(7), 2270-2279. https://doi. org/10.1111/j.1365-2486.2012.02696.x

Sevanto, S. (2014). Phloem transport and drought. Journal of Experimental Botany, 65(7), 1751-1759. https://doi.org/10.1093/jxb/ert467

Sevanto, S. (2018). Drought impacts on phloem transport. Current Opinion in Plant Biology, 43, 76-81. https://doi.org/10.1016/j.pbi.2018.01.002

Solberg, S. (2004). Summer drought: A driver for crown condition and mortality of Norway spruce in Norway. Forest Pathology, 34(2), 93104. https://doi.org/10.1111/j.1439-0329.2004.00351.x

Steinmann, K., Siegwolf, R. T. W., Saurer, M., \& Körner, C. (2004). Carbon fluxes to the soil in a mature temperate forest assessed by ${ }^{13} \mathrm{C}$ isotope tracing. Oecologia, 141(3), 489-501. https://doi.org/10.1007/ s00442-004-1674-4

Subke, J.-A., Vallack, H. W., Magnusson, T., Keel, S. G., Metcalfe, D. B., Högberg, P., \& Ineson, P. (2009). Short-term dynamics of abiotic and biotic soil ${ }^{13} \mathrm{CO}_{2}$ effluxes after in $\operatorname{situ}{ }^{13} \mathrm{CO}_{2}$ pulse labelling of a boreal pine forest. The New Phytologist, 183(2), 349-357. https://doi. org/10.1111/j.1469-8137.2009.02883.x

Teskey, R. O., Saveyn, A. N., Steppe, K., \& McGuire, M. A. (2008). Origin, fate and significance of $\mathrm{CO}_{2}$ in tree stems. The New Phytologist, 177(1), 17-32. https://doi.org/10.1111/j.1469-8137. 2007.02286.x

Tomasella, M., Beikircher, B., Häberle, K.-H., Hesse, B., Kallenbach, C., Matyssek, R., \& Mayr, S. (2018). Acclimation of branch and leaf hydraulics in adult Fagus sylvatica and Picea abies in a forest throughfall exclusion experiment. Tree Physiology, 38(2), 198-211. https:// doi.org/10.1093/treephys/tpx140

Ubierna, N., Marshall, J. D., \& Cernusak, L. A. (2009). A new method to measure carbon isotope composition of $\mathrm{CO}_{2}$ respired by trees: Stem $\mathrm{CO}_{2}$ equilibration. Functional Ecology, 23(6), 1050-1058. https://doi.org/10.1111/j.1365-2435.2009.01593.x

Unger, S., Máguas, C., Pereira, J. S., David, T. S., \& Werner, C. (2010). The influence of precipitation pulses on soil respiration - Assessing the "Birch effect" by stable carbon isotopes. Soil Biology and Biochemistry, 42(10), 1800-1810. https://doi.org/10.1016/j.soilbio.2010.06.019

van Bel, A. J. E. (2003). The phloem, a miracle of ingenuity. Plant, Cell \& Environment, 26(1), 125-149. https://doi.org/10.1046/j.1365-3040. 2003.00963.x van Mantgem, P. J., Stephenson, N. L., Byrne, J. C., Daniels, L. D., Franklin, J. F., Fulé, P. Z., Harmon, M. E., Larson, A. J., Smith, J. M., Taylor, A. H., \& Veblen, T. T. (2009). Widespread increase of tree mortality rates in the western United States. Science, 323(5913), 521-524. https://doi.org/10.1126/science.1165000

Wang, A., Siegwolf, R. T. W., Joseph, J., Thomas, F. M., Werner, W. Gessler, A., Rigling, A., Schaub, M., Saurer, M., Li, M.-H., \& Lehmann, M. M. (2021). Effects of soil moisture, needle age and leaf morphology on carbon and oxygen uptake, incorporation and allocation: $\mathrm{A}$ dual labeling approach with ${ }^{13} \mathrm{CO}_{2}$ and $\mathrm{H}_{2}{ }^{18} \mathrm{O}$ in foliage of a coniferous forest. Tree Physiology, 41(1), 50-62. https://doi.org/10.1093/ treephys/tpaa114

Wingate, L., Ogée, J., Burlett, R., Bosc, A., Devaux, M., Grace, J., Loustau, D., \& Gessler, A. (2010). Photosynthetic carbon isotope discrimination and its relationship to the carbon isotope signals of stem, soil and ecosystem respiration. The New Phytologist, 188(2), 576-589. https://doi.org/10.1111/j.1469-8137.2010.03384.x

Winkler, A., \& Oberhuber, W. (2017). Cambial response of Norway spruce to modified carbon availability by phloem girdling. Tree Physiology, 37(11), 1527-1535. https://doi.org/10.1093/treephys/tpx077

Woodruff, D. R. (2014). The impacts of water stress on phloem transport in Douglas-fir trees. Tree Physiology, 34(1), 5-14. https://doi. org/10.1093/treephys/tpt106

Zang, U., Goisser, M., Grams, T. E. E., Häberle, K.-H., Matyssek, R., Matzner, E., \& Borken, W. (2014). Fate of recently fixed carbon in European beech (Fagus sylvatica) saplings during drought and subsequent recovery. Tree Physiology, 34(1), 29-38. https://doi. org/10.1093/treephys/tpt110

Zwetsloot, M. J., \& Bauerle, T. L. (2021). Repetitive seasonal drought causes substantial species-specific shifts in fine-root longevity and spatio-temporal production patterns in mature temperate forest trees. The New Phytologist, 231(3), 974-986. https://doi. org/10.1111/nph.17432

\section{SUPPORTING INFORMATION}

Additional supporting information may be found in the online version of the article at the publisher's website.

How to cite this article: Hikino, K., Danzberger, J., Riedel, V. P., Rehschuh, R., Ruehr, N. K., Hesse, B. D., Lehmann, M. M., Buegger, F., Weikl, F., Pritsch, K., \& Grams, T. E. E. (2022). High resilience of carbon transport in long-term drought-stressed mature Norway spruce trees within 2 weeks after drought release. Global Change Biology, 28, 2095-2110. https://doi. org/10.1111/gcb.16051 